\title{
Tungsten-Promoted Intramolecular Alkoxycarbonylation for Synthesis of Complex Oxygenated Molecules
}

\author{
Chi-Chung Chen, ${ }^{\dagger}$ Jang-Shyang Fan, ${ }^{\dagger}$ Su-Ju Shieh, ${ }^{\dagger}$ Gene-Hsian Lee, ${ }^{\ddagger}$ \\ Shie-Ming Peng, ${ }^{\dagger}$ Sue-Lang Wang, ${ }^{\dagger}$ and Rai-Shung Liu*, ${ }^{*}$
}

\begin{abstract}
Contribution from the Department of Chemistry, National Tsing Hua University, Hsinchu, 30043, Taiwan, Republic of China, and Department of Chemistry, National Taiwan University, Taipei, 10764, Taiwan, Republic of China
\end{abstract}

Received May 28, $1996^{\otimes}$

\begin{abstract}
Intramolecular alkoxycarbonylation of tungsten-propargyl compounds proceeds with excellent diastereoselectivities to form $\eta^{3}-\delta$ - and $-\epsilon$-lactones but for $\gamma$-lactones. With $\mathrm{OSi}(t-\mathrm{Bu}) \mathrm{Me}_{2}$ substituted for an $\alpha$-hydroxy group, $\eta^{3}-\gamma$-lactones are stereoselectively formed with syn stereoselection. An optically active tungsten $\eta^{3}-\gamma$-lactone is prepared from D-(+)-xylose to illustrate the stereochemical effect of $\mathrm{OSi}(t-\mathrm{Bu}) \mathrm{Me}_{2}$. All these $\eta^{3}-\gamma-,-\delta$-, and $-\epsilon$-lactones are converted to allyl anions that react in situ with aldehydes and ketones to produce various $\beta$-(hydroxylalkyl)- $\alpha$-methylene- $\gamma$-lactones with good diastereoselectivity. This reaction is also applied to the synthesis of chiral $\alpha$-methylene butyrolactones. Organic carbonyls add to the $\pi$-allyl groups of $\eta^{3}-\gamma$-and $-\delta$-lactones opposite the tungsten fragment, whereas additions occur from the metal side for $\eta^{3}$ - $\epsilon$-lactones. The stereochemical courses of these reactions are discussed in detail. These two tungsten-promoted reactions efficiently effect stereoselective transformation of chloroalkynols to complex $\alpha$-methylene- $\gamma$-lactones, which are useful materials for syntheses of trisubstituted 1,3-, 1,4-, and 1-5-diols.
\end{abstract}

\section{Introduction}

Metal-mediated intramolecular alkoxycarbonylation is very useful for the syntheses of oxygenated heterocycles. ${ }^{1-5} \mathrm{~A}$ number of reactions are performed catalytically with complexes of late transition metals such as $\operatorname{Pd}(0),{ }^{2} \operatorname{Rh}(\mathrm{I}),{ }^{3}$ and $\mathrm{Ni}(0) .{ }^{3}$

${ }^{\dagger}$ National Tsing Hua University.

* National Taiwan University.

${ }^{\otimes}$ Abstract published in Advance ACS Abstracts, September 15, 1996.

(1) (a) Heck, R. F.; Wu, G.; Tao, W.; Rheingold, A. L. In Catalysis of Organic Reactions; Blackburn, D. W., Ed.; Marcel Decker Inc.: New York, 1990; p 169. (b) Collman, J. P.; Hegedus, L. S.; Norton, J. R.; Finke, R. G. Principles and Application of Organotransition Metal Chemistry; University Science Books: Mill Valley, CA, 1987; Chapter 12, p 619. (c) Hegedus, L. S. Transition Metals in the Synthesis of Complex Organic Molecules; University Science Books: Mill Valley, CA, 1994; Chapter 4, p 103. (d) Bates R. W. In Comprehensive Organometallic Chemistry, Vol. 12: Transition Metal Organometallics In Organic Synthesis: Abel, E. W., Stone, F. G. A., Wilkinson, G, Eds.; Pergamon Press: Oxford, UK, 1995; Chapter $4, \mathrm{p} 349$.

(2) For representative examples of catalytic alkoxycarbonylation using palladium complexes: (a) Murray, T. F.; Norton, J. R. J. Am. Chem. Soc. 1979, 101, 4107. (b) Negishi, E. I.; Sawada, H.; Tour, J. M.; Wei, Y. J. Org. Chem. 1988, 53, 913. (c) Tsuji, Y.; Kondo, T.; Watanabe, Y. J. Mol. Catal. 1987, 40, 295. (d) Shinoyama, I.; Zhang, Y.; Wu, G.; Negishi, E.-I. Tetrahedron Lett. 1990, 31, 2841.

(3) $\mathrm{Ni}(0)$ and $\mathrm{Rh}(1)$ complexes for catalytic alkoxycarbonylation See representative examples: (a) Semmelhack, M. F.; Brickner, S. J. J Am. Chem. Soc. 1981, 103, 3945. (b) Sammelhack, M. F.; Brincker, S. J. J. Org. Chem. 1981, 46, 1723. (c) Eguchi, M.; Zeng, Q.; Korda, A.; Ojima, I. Tetrahedron Lett. 1993, 34, 915. (d) Matsuda, I.; Ogiso, A.; Sato, S. J. Am. Chem. Soc. 1990, 112, 6120. (e) Matsuda, I. Chem. Lett. 1978, 773.

(4) For examples of stoichiometric cyclocarbonylation, see: (a) Schrieber, S. L.; Semmekia, T.; Crowe, W. E. J. Am. Chem. Soc. 1986, 108, 3128. (b) Billington, D. C.; Pauson, P. L. Organometallics 1982, 1, 1560. (c) Magnus, P.; Principe, M. J.; Slater, J. J. Org. Chem. 1987, 52, 1483. (d) Berk, S. C.; Grossman, S. L.; Buchwald, S. L. J. Am. Chem. Soc. 1993, 115, 4912. (e) Frank-Neuman, M.; Michelotti, E. L.; Simler, R.; Vernier, J. M. Tetrahedron Lett. 1992, 33, 7361.

(5) For examples of stoichiometric alkoxycarbonylation, see: (a) Ley, S, V. Philos. Trans. R. Soc. London A 1988, 326, 633. (b) Caruso, M.; Knight, J. G.; Ley, S. V. Synlett 1990, 331 (c) Ring, H.; Auman, R.; Frohlich, K. Angew. Chem.,Int. Ed. Engl. 1974, 13, 275. (d) Moriarty, R. M.; Deboer, B. J.; Churchill M. R.; Yeh, H. J. S.; Chen, K. N. J. Am. Chem. Soc. 1975, 97, 5602. (e) Liebeskind, L. S.; Welker, M., Fengl, R. W. J. Am. Chem. Soc. 1986, 108, 6328. (f) Davies, S, G.; Dordor-Hedgecock, I. M.; Warnrer, P. L. Tetrahedron Lett. 1985, 26, 2125.

\section{Scheme 1}

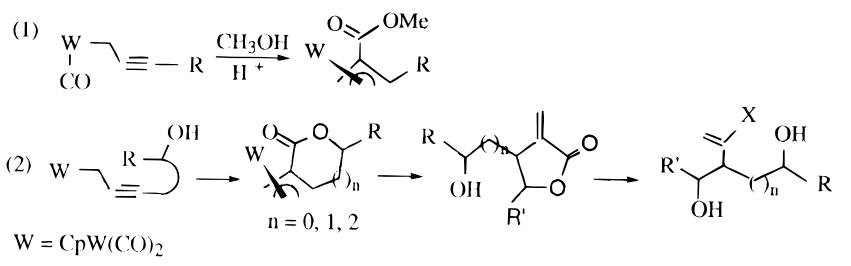

Although stoichiometric alkoxycarbonylation ${ }^{4,5}$ is less economical, it may be accessible to more complex molecules if stereocontrolled functionalization can be implemented sequentially. Tungsten - propargyl compounds undergo facile protoncatalyzed alkoxycarbonylation ${ }^{6}$ to yield tungsten $-\eta^{3}$-allyl compounds as shown in Scheme 1; this reaction allows three chemical bonds to form simultaneously. We here report efficient diastereoselective syntheses of acyclic oxygenated compounds with intramolecular alkoxycarbonylation of propargyl compounds as the initial step. The resulting tungsten$\eta^{3}-\gamma,-\delta$, and - $\epsilon$-lactonyl compounds are subsequently transformed to complex $\alpha$-methylene butyrolactones in a one-pot operation. The two reactions proceed highly stereoselectively; the stereochemical courses are discussed later in detail. These resulting lactones provide trisubstituted 1,3- ${ }^{7-8} 1,4-{ }^{9}$ and 1,5$\operatorname{diols}^{10}$ after opening of the lactone ring. Stereoselective syntheses of acyclic diols at remote positions are challenging issues $^{7-10}$ in organic chemistry.

(6) For alkoxylcarbonylation of metal- $\eta^{1}$-propargyl compounds, see: (a) Charrier, C.; Collin, J.; Merour, J. Y.; Roustan, J. L. J. Organomet. Chem. 1978, 162, 57. (b) Cheng, M.-H.; Ho, Y. H.; Chen, C. H.; Lee, G. H.; Peng, S. M.; Chu, S. Y.; Liu, R. S. Organometallics 1994, 13, 4082. (c) Lin, S. H.; Vong, W. J.; Liu, R. S. Organometallics 1995, 14, 1619.

(7) Oishi, T.; Nakata, T. Synthesis 1990, 635

(8) Representative examples for stereoselective synthesis of 1,3-diols See the review paper ${ }^{7}$ and: (a) Evans, D. A.; Chapman, K. T.; Carreira E. M. J. Am. Chem. Soc. 1988, 110, 3560 (b) Evans, D. A.; Hoveyda, A. H. J. Org. Chem. 1990, 55, 5190. (c) Rychnovsky, S. D.; Griesgraber, G.; Zeller, S.; Skalitzky, D. L. J. Org. Chem. 1991, 56, 5161. (d) Hanamoto, T.; Hiyama, T. Tetrahedron Lett. 1988, 29, 6467. (e) Narasaka, K.; Pai, F.-C. Chem. Lett. 1980, 1415. 
Scheme 2

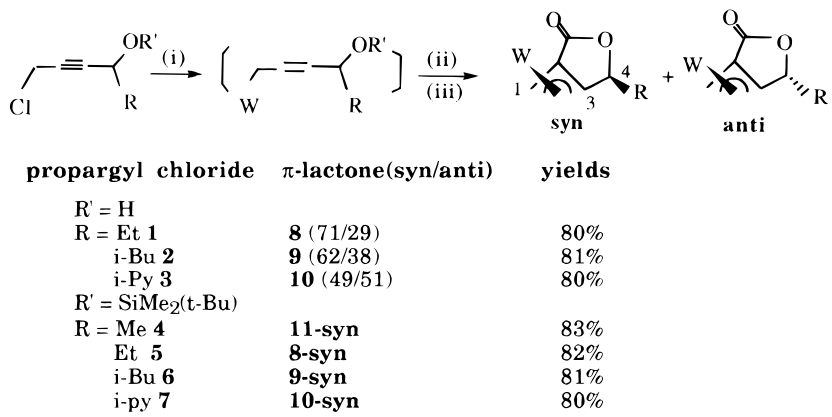

$\mathrm{W}=\mathrm{CpW}(\mathrm{CO})_{2,}$, (i) $\mathrm{CpW}(\mathrm{CO})_{3} \mathrm{Na}\left(1.0\right.$ equiv., $\left.23^{\circ} \mathrm{C}, 4 \mathrm{~h}\right)$ (ii) $\mathrm{CF}_{3} \mathrm{SO}_{3} \mathrm{H}(0.25$ equiv, - $\left.40^{\circ} \mathrm{C}, 1 \mathrm{~h}\right)$ (iii) $\mathrm{R}=\mathrm{SiMe}_{2}(\mathrm{t}-\mathrm{Bu}), \mathrm{H}_{2} \mathrm{O}(1.0-2.0$ equiv. $)$.

\section{Scheme 3}

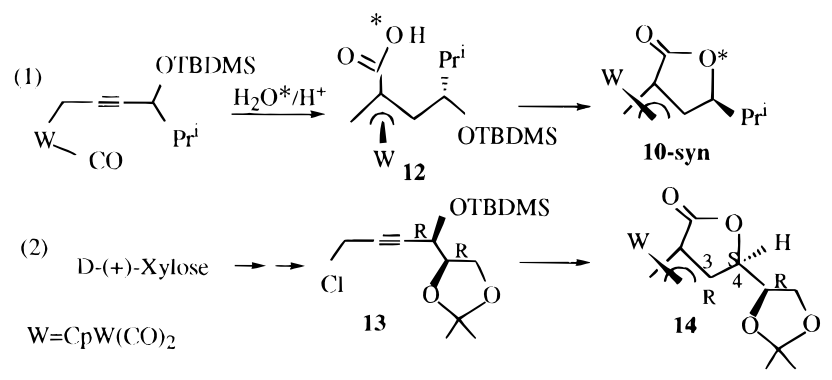

\section{Results}

Stereoselective Syntheses of Tungsten $-\eta^{3}-\gamma,-\delta$, and $-\epsilon-$ Lactonyl Compounds. Treatment of 4-chloro-2-yn-1-ols ${ }^{11} \mathbf{1}-\mathbf{3}$ with $\mathrm{NaCpW}(\mathrm{CO})_{3}$ (1.0 equiv) in tetrahydrofuran (THF) (23 ${ }^{\circ} \mathrm{C}$ ), followed by acidification of the resulting $\eta^{1}$-propargyl compounds with catalyst $\mathrm{CF}_{3} \mathrm{SO}_{3} \mathrm{H}\left(0.15\right.$ equiv) in cold $\mathrm{CH}_{2}$ $\mathrm{Cl}_{2}\left(-40{ }^{\circ} \mathrm{C}, 4 \mathrm{~h}\right)$, delivered $\eta^{3}-\gamma$-lactonyl compounds 8-10 as a mixture of syn and anti diastereomers (syn/anti $=2.5-$ 1.0); the overall yields exceeded $80 \%$ (Scheme 2). The two diastereomers are distinguishable by proton NMR spectra that showed coupling constants $J_{34}=0 \mathrm{~Hz}$ for the anti isomer and $J_{34}=3-4 \mathrm{~Hz}$ for the $s y n$ isomer. Separation of the mixtures by fractional crystallization and column chromatography was very difficult. To circumvent this stereochemical problem, we discovered that acidification of $\alpha$-(silyloxy)tungsten $-\eta^{1}$-propargyl species with $\mathrm{CF}_{3} \mathrm{SO}_{3} \mathrm{H}$ in cold $\mathrm{CH}_{2} \mathrm{Cl}_{2}\left(-40{ }^{\circ} \mathrm{C}, 3 \mathrm{~h}\right)$ yielded only syn isomers of $\mathbf{8 - 1 1}$, even for the bulky isopropyl group; the overall yields also exceeded $80 \%$ propargyl chloride $\pi$-lactone(syn/anti)yields (Scheme 2). A little water (1.0-2.0 equiv) is a prerequisite for this syn stereoselection. The syn isomer of 9 was characterized by an X-ray diffraction study. ${ }^{12,13}$ The effect of the $\alpha$-(tert-butyl)dimethylsilyl group on syn stereoselectivity deserves attention. As depicted in Scheme 3, we monitored the $\mathrm{CF}_{3} \mathrm{SO}_{3} \mathrm{H} / \mathrm{H}_{2} \mathrm{O}$ acidification of an $\alpha$-silyloxy

(9) Examples for stereoselective synthesis of 1,4-diols, see: (a) Narasaka, K.; Ukaji, Y.; Watanabe, K., Bull. Chem. Soc. Jpn. 1987, 60, 1457. (b) Reetz, M. T.; Kesseler, K.; Schmidtberger, S.; Wenderoth, B.; Steinbach, R. Angew. Chem., Int. Ed. Engl. 1983, 22, 989. (c) Bartlett, P. A., Jernstedt, K. K. J. Am. Chem. Soc. 1977, 99, 4829. (d) Wilson, S. R.; Price, M. F. Tetrahedron Lett. 1983, 24, 569.

(10) Examples for stereoselective synthesis of 1,5-diols. See: (a) Zheng, H.-C.; Costanzo, M. J.; Maryanoff, B. Tetrahedron Lett. 1994, 35, 4891. (b) Solladie, G.; Huser, N. Tetrahedron Lett. 1994, 35, 5297. (c) Burk, M. J.; Feaster, J. E.; Harlow, R. L. Tetrahedron: Asymmetry 1991, 2, 569. (d) Panek, J. S.; Yang, M.; Solomon, J. S., J. Org. Chem. 1993, 58, 1003. (e) Short, R. P.; Kennedy, R. M.; Masamune, S. J. Org. Chem. 1989, 54, 1755.

(11) Brandsma, L.; Verkruijsse, H. D. Synthesis of Acetylenes, Allenes and Cumulenes; Elsevier: New York, 1984; Chapter 1.

(12) Crystal data, ORTEP drawing, and structure factors of compounds $\mathbf{9}, \mathbf{1 8}, \mathbf{1 9}, \mathbf{2 4}$, and 27 have appeared in the communication of this work; ${ }^{13}$ these repetitive data will not be reported in this article.

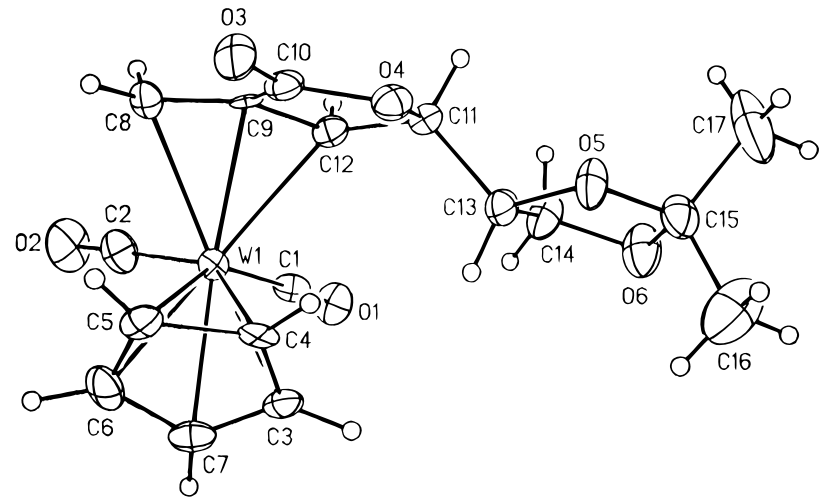

Figure 1. ORTEP drawing of chiral tungsten $-\eta^{3}$-allyl complex 14 . Selected bond distances $(\AA): \mathrm{W}(1)-\mathrm{C}(8)=2.320(12) ; \mathrm{W}(1)-\mathrm{C}(9)=$ $2.221(10) ; \mathrm{W}(1)-\mathrm{C}(12)=2.361(12) ; \mathrm{C}(9)-\mathrm{C}(10)=1.506(15) ; \mathrm{C}(10)-$ $\mathrm{O}(3)=1.192(13)$.

$\eta^{1}$-propargyl complex in proton NMR experiments $\left(-40{ }^{\circ} \mathrm{C}\right.$, $\left.\mathrm{CDCl}_{3}\right)$. After a brief interval $(t=3 \mathrm{~min})$, the solution species consisted of tungsten-allyl complex 12 ( $~ 90 \%$ yield) and syn$\eta^{3}$-lactonyl species $10(\sim 10 \%)$. Species 12 was kinetically unstable in this acidic medium. After a prolonged period $(t=$ $3 \mathrm{~h}$ ), the NMR signals of $\mathbf{1 2}$ disappeared completely to leave 10-syn as the only species $(\sim 96 \%)$ remaining in solution. Quenching the solution with $\mathrm{NaHCO}_{3}$ after a brief time $(t=3$ min) allowed isolation of $\mathbf{1 2}$ in $51 \%$ yield. Alternatively, treatment of the $\eta^{1}$-propargyl complex with $\mathrm{CF}_{3} \mathrm{CO}_{2} \mathrm{H} / \mathrm{H}_{2} \mathrm{O}$ in cold $\mathrm{CH}_{2} \mathrm{Cl}_{2}\left(-40{ }^{\circ} \mathrm{C}, 2 \mathrm{~h}\right)$ yielded 12 in $73 \%$ yield. In the latter case, when 1.0 equiv of $\mathrm{H}_{2}{ }^{18} \mathrm{O}$ was used, the isotopic content of the resulting lactone 10-syn was $80-85 \%$. We prepared chiral propargyl chloride $\mathbf{1 3}^{14}$ derived from D-(+)xylose to understand the reaction mechanism for syn stereoselection. The chiral syn-lactone $14\left([\alpha]=110.9^{\circ}, c=0.10\right.$, $\mathrm{CH}_{2} \mathrm{Cl}_{2}$ ) was produced smoothly from 13 in an overall yield of $70 \%$. The molecular structure of $\mathbf{1 4}$ (Figure 1) revealed that the $\mathrm{C}(3)$ and $\mathrm{C}(4)$ carbon configurations are $R$ and $S$, respectively; this configuration at $\mathrm{C}(4)$ implies that formation of the $\mathrm{C}(4)-\mathrm{O}$ bond of $\mathbf{1 4}$ proceeds with retention of stereochemistry relative to $\mathbf{1 3}$.

Following the same method, tungsten $-\eta^{3}-\delta$-lactonyl compounds 18-20 were obtained from the reactions between $\mathrm{CpW}$ (CO) ${ }_{3} \mathrm{Na}$ and 5-chloro-3-yn-1-ols as depicted in Scheme 4. This alkoxycarbonylation proceeds with excellent diastereoselectivity to yield only anti diastereomer according to X-ray structures of 18 and 19;12 the overall yields exceeded $80 \%$. Further treatment of 19 with $\mathrm{NOBF}_{4}$ (1.0 equiv) in $\mathrm{CH}_{3} \mathrm{CN}\left(0{ }^{\circ} \mathrm{C}\right)$ produced an allyl cation ${ }^{15}$ which reacted with $\mathrm{Bu}_{4} \mathrm{NBH}_{4}$ to yield unsaturated lactone $\mathbf{2 1}$ in $86 \%$ yield. Scheme 4 also shows the formation of tungsten $-\eta^{3}-\epsilon$-lactonyl compounds 24 and 25 derived from 6-chloro-4-yn-1-ols 22 and $\mathbf{2 3} ;{ }^{11}$ the overall yields exceeded $80 \%$. Likewise, the reactions proceeded with such excellent diastereoselectivity that only one diastereomer was observed according to variable temperature NMR spectra. Proton NMR spectra at $-40{ }^{\circ} \mathrm{C}$ revealed that compounds 24 and 25 exist as two conformational isomers; the endo/exo ratios ${ }^{16}$ were $\mathbf{1 / 2}$ and $\mathbf{2 / 5}$ for compounds $\mathbf{2 4}$ and $\mathbf{2 5}$, respectively. Activation energies for the endo/exo exchange were estimated to be 13.8 and $13.9 \mathrm{kcal} / \mathrm{mol}$ for $\mathbf{2 4}$ and $\mathbf{2 5}$, respectively. The

(13) Preliminary results of this work: Chen, C.-C.; Fan, J.-S.; Lee, G.H.; Peng, S.-M.; Wang, S.-L.; Liu, R.-S. J. Am. Chem. Soc. 1995, 117, 2933.

(14) (a) Yadav, J. S.; Chander, M. C.; Joshi, B. V. Tetrahedron Lett. 1988, 2737. (b) Takano, S.; Akiyama, M.; Sugihara, T.; Ogasawara, K. Heterocycles 1992, 33, 831 .

(15) Faller, J. W.; Chen. C. C.; Mattina, M. J.; Jakubowski, A. J. Organomet. Chem. 1973, 52, 361. 


\section{Scheme 4}

(1)

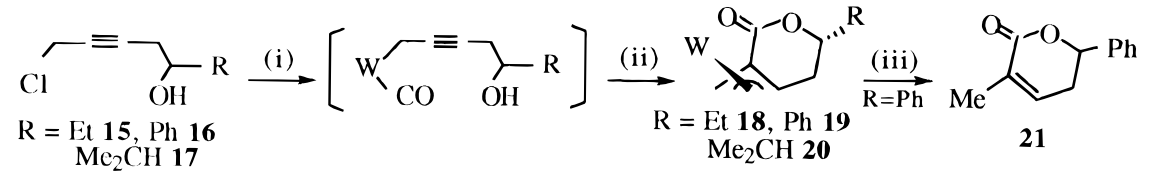

(2)
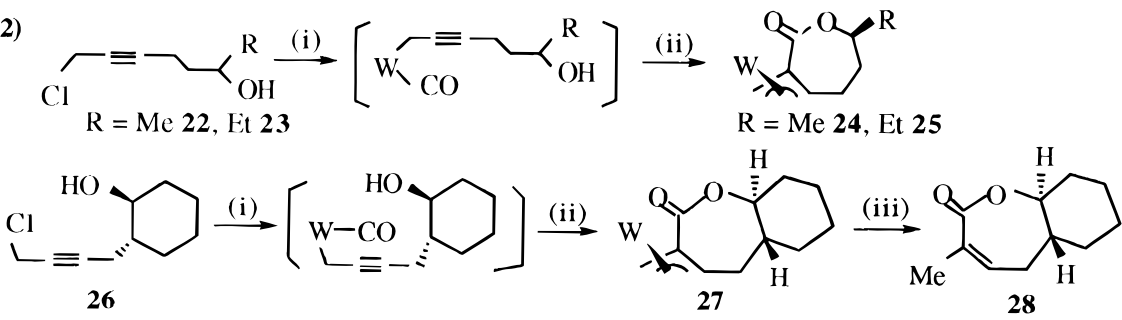

$\mathrm{W}=\mathrm{CpW}(\mathrm{CO})_{2}$, (i) $\mathrm{CpW}(\mathrm{CO})_{3} \mathrm{Na}\left(\mathrm{THF}, 23{ }^{0} \mathrm{C}, 4 \mathrm{~h}\right)\left(\right.$ ii) $\mathrm{CF}_{3} \mathrm{SO}_{3} \mathrm{H}\left(0.25\right.$ equiv., $\left.\mathrm{CH}_{2} \mathrm{Cl}_{2}-40^{0} \mathrm{C}, 1 \mathrm{~h}\right)$

(iii) $\mathrm{NOBF}_{4}\left(1.0\right.$ equiv, $\left.\mathrm{CH}_{3} \mathrm{CN}, 0{ }^{\circ} \mathrm{C}\right), \mathrm{Bu}_{4} \mathrm{NBH}_{4}\left(3.0\right.$ equiv, $\left.0{ }^{\circ} \mathrm{C}\right)$

crystal structures of $\mathbf{2 4}$ was determined from X-ray diffraction studies $^{12}$ that confirmed the syn configuration i. e., the ethyl group lies on the metal side. To apply this method to a more complex molecule, we synthesized the propargyl halide $\mathbf{2 6}$, further converting it to an $\eta^{1}$-propargyl species, and finally yielding $\eta^{3}$-bicyclic lactone 27 in overall yield $76 \%$. The X-ray structure of $27^{12}$ revealed that the cyclization also follows syn stereoselection. Sequential treatment of 27 with $\mathrm{NOBF}_{4}{ }^{16}$ and $\mathrm{Bu}_{4} \mathrm{NBH}_{4}$ in $\mathrm{CH}_{3} \mathrm{CN}$ afforded bicyclic unsaturated lactone 28 in $91 \%$ yield.

Condensation of $\boldsymbol{\eta}^{\mathbf{3}}$-Lactonyl Complexes with Organic Carbonyls. $\mathrm{CpMo}(\mathrm{NO}) \mathrm{X}(\pi$-allyl $)(\mathrm{X}=\text { halide })^{17,18}$ reacted with aldehydes to yield homoallylic alcohols with high diastereoselectivity. This method was developed by Faller ${ }^{17,18}$ for molybdenum complexes. We discovered that the reaction is applicable to our tungsten $\eta^{3}$-lactonyl compounds for stereocontrolled syntheses of complex $\alpha$-methylene butyrolactones; the operation is carried out in a one-pot procedure to achieve maximum yields. In a typical example, treatment of $s y n-\eta^{3}$ $\gamma$-lactonyl 11-syn with $\mathrm{NOBF}_{4}\left(1.0\right.$ equiv) in $\mathrm{CH}_{3} \mathrm{CN}\left(0{ }^{\circ} \mathrm{C}\right)$, followed by addition of $\mathrm{NaI}$ (2.0 equiv), gave a $\mathrm{CpW}(\mathrm{NO}) \mathrm{I}(\pi$ allyl) species (vide infra) that reacted in situ with aldehydes $\left(\mathrm{CH}_{3} \mathrm{CN}, 23{ }^{\circ} \mathrm{C}, 4 \mathrm{~h}\right)$ to give 29 in overall yield $65 \%$ after workup. Scheme 5 summarizes all results for condensation of $\eta^{3}$-lactonyl compounds $\mathbf{8}, \mathbf{9}$, and $\mathbf{1 1}$ with various organic carbonyl compounds. All the reactions in this scheme proceeded with good diastereoselectivities such that one dominant product was formed. Although $\mathrm{CpMo}(\mathrm{NO}) \mathrm{X}(\pi$-allyl $)(\mathrm{X}=$ halide $)$ failed to react with ketones, condensation of several methyl ketones with 8 -syn or $\mathbf{9}$-syn yielded the corresponding $\alpha$ methylene butyrolactones $\mathbf{3 3 - 3 5}$ in reasonable yields, 55-60\% (entries 5-7). The reaction between 9-syn and diethyl ketone failed to yield $\alpha$-methylene butyrolactone even after $48 \mathrm{~h}$. $\mathrm{CpW}(\mathrm{NO}) \mathrm{I}(\pi$-allyl $)$ compounds were more reactive than molybdenum analogs without loss of diastereoselectivities. The stereochemical outcome shown in Scheme 5 reveals that the forming carbon-carbon bonds proceed via inversion of stereochemistry relative to the tungsten fragment.

Compounds 29, 30, and 33 have a trans configuration according to NOE effects and the proton coupling constant $J_{45}$

(16) Adams, R. D.; Chodosh, D. F.; Faller, J. W.; Rosan, A. M. J. Am. Chem. Soc. 1979, 101, 2570.

(17) (a) Faller, J. W.; Linebarrier, D. L. J. Am. Chem. Soc. 1989, 111, 1937. (b) Faller, J. W.; John, J. A.; Mazzier, M. R. Tetrahedron Lett. 1989, 32, 1769. (c) Faller, J. W.; DiVerdi, M. J.; John, J. A.; Tetrahedron Lett. 1989, 32, 1271. (d) Faller, J. W.; Naguyen, J. T.; Ellis, W.; Mazzieri, M. R. Organometallics 1993, 12, 1434.

(18) Faller, J. W.; Ma, Y. J. Am. Chem. Soc. 1991, 113, 1579. (b) Faller, J. W.; Chase, K. J.; Mazzieri, M. R. Inorg. Chim. Acta 1995, 229, 39. (c) Faller, J. W. Nguyen, J. T.; Mazzieri, M. R. Appl. Organomet. Chem. 1995, 9, 291.

\section{Scheme 5}

Entry

Scheme 6

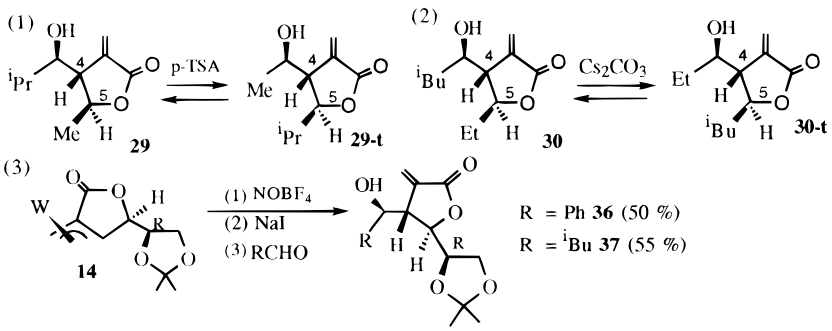

$=3-4 \mathrm{~Hz}$. The magnitude of the cis coupling constant is $\sim J_{45}$ $=8-10 \mathrm{~Hz} \cdot{ }^{6 \mathrm{c}}$ Treatment of $\mathbf{2 9}$ with $p$-toluenesulfonic acid $(p$ TSA) $(20 \mathrm{~mol} \%)$ in $\mathrm{CH}_{2} \mathrm{Cl}_{2}\left(23{ }^{\circ} \mathrm{C}, 4\right.$ days $)$ produced a trans esterification isomer 29-t that attained an equilibrium with $\mathbf{2 9}$ in a ratio $29-\mathrm{t} / \mathbf{2 9}=3 / 1$, further separable on a silica TLC plate. Proton NOE spectra of 29-t indicated a trans configuration of the lactone. Similarly heating of $\mathbf{3 0}$ with $\mathrm{Cs}_{2} \mathrm{CO}_{3}$ in THF for 4 $\mathrm{h}$ produced 30 and 30-t in equal proportion. Compound 30-t likewise has a trans configuration according to the proton $\mathrm{NOE}$ 


\section{Scheme 7}

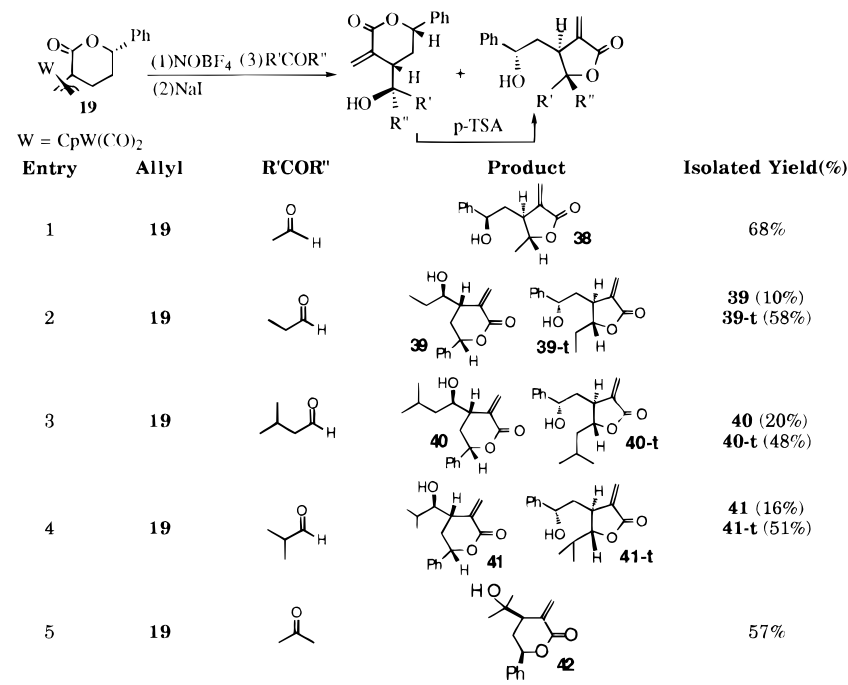

effect, thus establishing the complete stereochemistry of the products. Equation 3 shows the application to the syntheses of chiral compounds $36\left([\alpha]=-23.0, c=0.76, \mathrm{CHCl}_{3}\right)$ and 37 $\left([\alpha]=+9.4, c=1.26, \mathrm{CHCl}_{3}\right)$ in yields 50 and $57 \%$, respectively. 36 has a trans configuration according to proton NMR data.

Scheme 7 presents the results for condensation of $\eta^{3}-\delta$ lactonyl 19 with aldehydes and ketones according to the same procedure. As a specific instance, the reaction between propanal and 19 afforded a mixture of 39 (10\%) and 39-t (58\%, a trans esterification isomer of 39), separable on a silica TLC plate. Compounds 39 and 39-t were identified to be $\delta$ - and $\gamma$-lactone, respectively, according to ${ }^{1} \mathrm{H}$ and ${ }^{13} \mathrm{C}$ NMR data. Treatment of $\delta$-lactone 39 with $p$-TSA catalyst $(10 \mathrm{~mol} \%)$ in $\mathrm{CDCl}_{3}(23$ ${ }^{\circ} \mathrm{C}, 6 \mathrm{~h}$ ) regenerated 39-t in an equilibrium ratio 39/39- $\mathrm{t}=1 / 10$, confirming the structural relationship between the two compounds. Proton NOE effects revealed cis and trans configurations of 39 and 39-t, respectively (see the Experimental Section), thus establishing the complete stereochemistry of the products. Likewise, treatment of $\mathbf{4 0}$ and $\mathbf{4 1}$ with $p$-TSA (10 mol \%) in $\mathrm{CDCl}_{3}\left(23{ }^{\circ} \mathrm{C}, 4 \mathrm{~h}\right)$ produced their respective isomers $40 \mathrm{t}$ and 41t with equilibria in favor of $\gamma$-lactones $(\mathbf{4 0} / \mathbf{4 0} \mathrm{t}=1 / 10, \mathbf{4 1}$ / $\mathbf{4 1} \mathrm{t}=1 / 13)$. The reaction of 19 with acetone gave a $57 \%$ yield of 42 (entry 5), which was not converted to $\gamma$-lactone by $p$-TSA in $\mathrm{CDCl}_{3}\left(23{ }^{\circ} \mathrm{C}, 4 \mathrm{~h}\right)$.

Scheme 8 shows the results for $\eta^{3}$ - $\epsilon$-lactone complexes $\mathbf{2 4}$ and $\mathbf{2 5}$ according to the same method; in most cases only a single isomer of $\alpha$-methylene butyrolactone was formed. In entry $1,{ }^{1} \mathrm{H}$ NMR spectra of $\mathbf{4 3 a}$ and $\mathbf{4 3 b}(\sim 5 / 1$ ratio) are similar but are distinct through their methyl signals; the existence of two diastereomers was clearly indicated in ${ }^{13} \mathrm{C}$ NMR spectra. The two diastereomers of $\mathbf{4 3 a}-\mathbf{b}$ and $\mathbf{4 7 a}-\mathbf{b}$ appear to have the same configurations at the $\gamma$-lactone ring because of slight differences $(\Delta \delta<0.02 \mathrm{ppm})$ in the proton NMR chemical shifts. Proton NOE spectra of $\mathbf{4 3 a}$ and $\mathbf{4 8}$ show a trans configuration. To determine the complete stereochemistry, as shown in Scheme 9 , we converted the major diastereomer 43a to its triethylsiloxy derivative 49, followed by treatment with excess MeLi to yield $\mathbf{5 0}$ as a crystalline solid. The molecular structure of $\mathbf{5 0}$ was determined from an X-ray diffraction study. ${ }^{19}$ Intramolecular cyclization of the mesylate derivative $\mathbf{5 1}$ afforded tetrahydropyran $\mathbf{5 2}$ in $92 \%$ yield. The proton NOE results and proton coupling constants of $\mathbf{5 2}$ establish the stereochemistry (see Experimental Section) that is consistent with the X-ray structure
Scheme 8

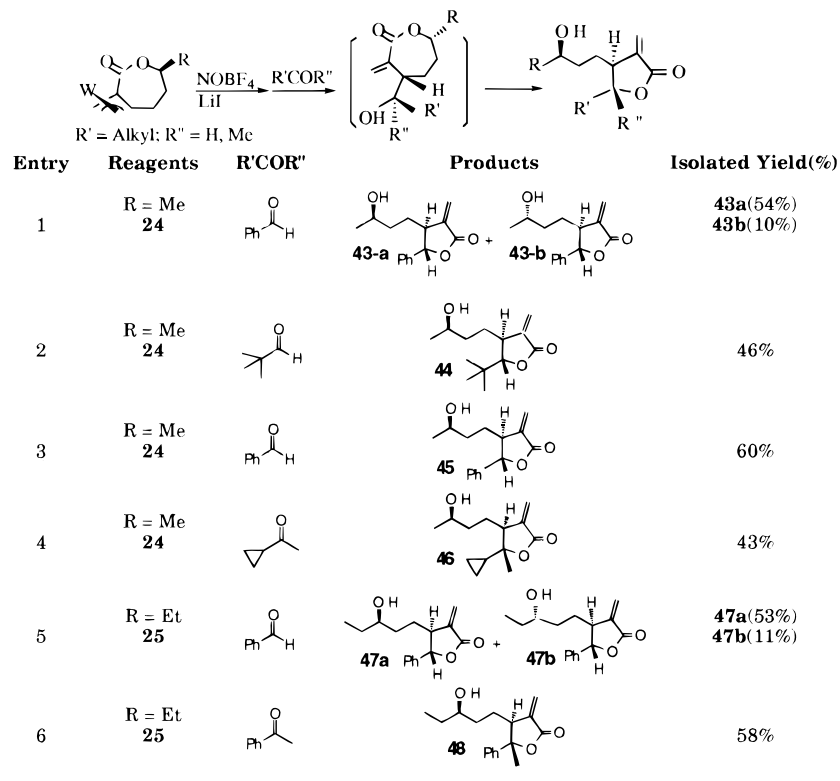

Scheme 9

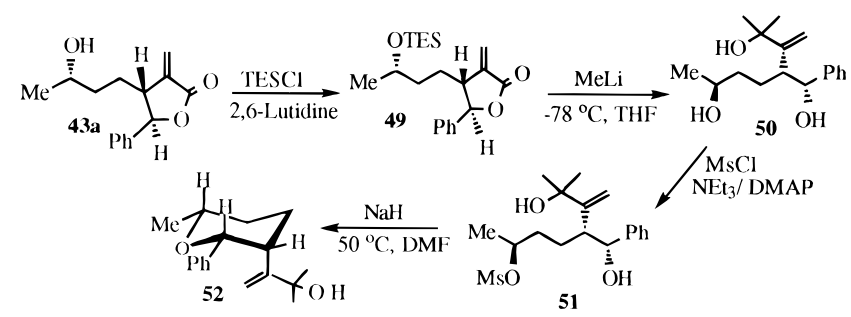

Scheme 10

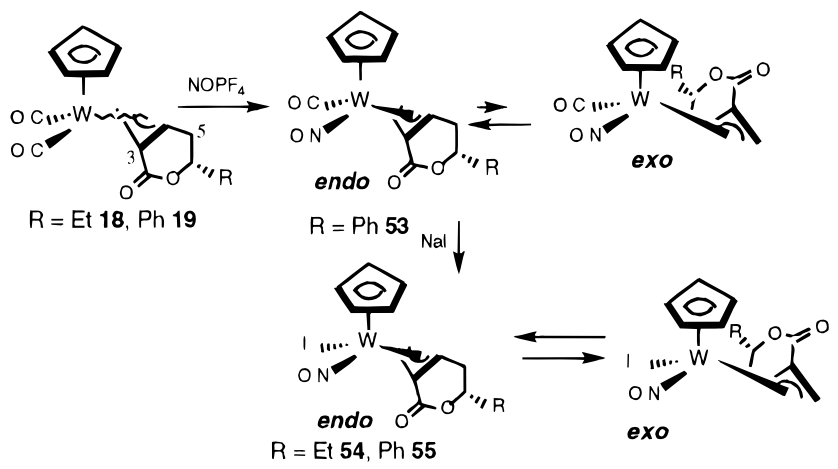

of 50. As shown in Scheme 8, cis- $\epsilon$-lactones are envisaged to be the primary reaction products that undergo rapid trans esterification to yield the observed single (major) diastereomer. Minor products $\mathbf{4 3 b}$ and $\mathbf{4 7 b}$ are derived from the primary trans$\epsilon$-lactone form. Formation of cis- $\epsilon$-lactones indicates that the carbonyl addition at the tungsten allyl group occurs preferentially on the same side as the tungsten fragment, i.e., with retention of stereochemistry.

Characterization of $\mathrm{CpW}(\mathrm{NO}) \mathrm{I}\left(\boldsymbol{\eta}^{3}\right.$-Lactonyl) Complexes. To clarify the structure of $\mathrm{CpW}(\mathrm{NO}) \mathrm{I}\left(\eta^{3}\right.$-lactonyl), it is very useful to elucidate the stereochemical courses of the preceding organic reactions. Scheme 10 shows syntheses of the $\mathrm{CpW}$ (CO) $\mathrm{NO}^{+}$and $\mathrm{CpW}(\mathrm{NO}) \mathrm{I}$ compounds 53-55 derived from 18 and 19. Preparation of pure $\mathbf{5 5}$ from nitrosyl salt $\mathbf{5 3}$ was achieved in $83 \%$ yield by fractional crystallization from acetonitrile/diethyl ether. Sequential treatment of 18 with $\mathrm{NOPF}_{6}$ and then $\mathrm{NaI}$ in $\mathrm{CH}_{3} \mathrm{CN}(5 \mathrm{~mL})$ at $0{ }^{\circ} \mathrm{C}$ gave 54 in an

(19) The ORTEP drawing and crystal data of 1,5-diol $\mathbf{5 0}$ were prepared as supporting information. 

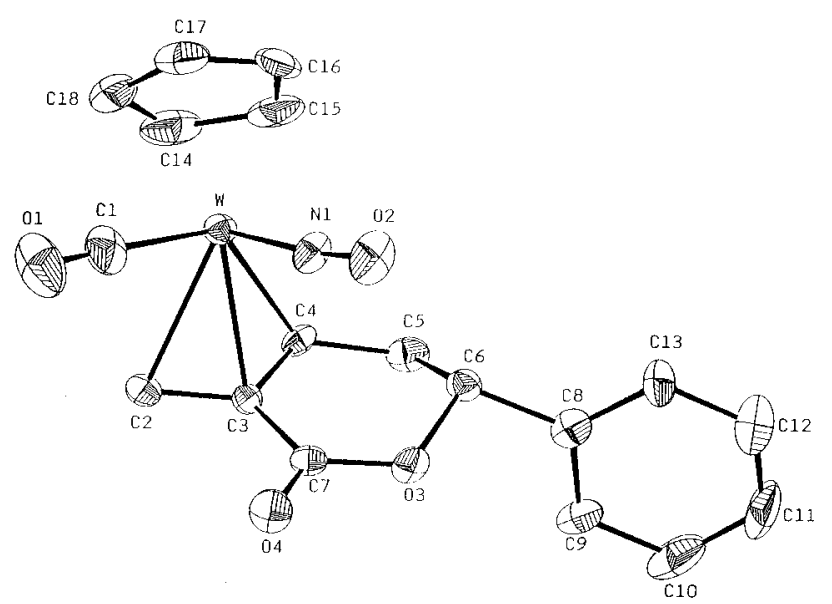

Figure 2. ORTEP drawing of compound 53. Selected bond distances $(\mathrm{A}): \mathrm{W}-\mathrm{C}(2)=2.348(12) ; \mathrm{W}-\mathrm{C}(3)=2.315(10) ; \mathrm{W}-\mathrm{C}(4)=2.364-$ (10); $\mathrm{C}(3)-\mathrm{C}(7)=1.486(16) ; \mathrm{C}(7)-\mathrm{O}(4)=1.197(12)$.

overall yield of $72 \%$ after recrystallization. As expected, the reaction of 55 with acetaldehyde in $\mathrm{CH}_{3} \mathrm{CN}\left(23^{\circ} \mathrm{C}, 4 \mathrm{~h}\right)$ afforded only 38, consistent with the result from a direct synthesis (Scheme 7, entry 1); the latter is more convenient and efficient. Only one diastereomer was found for $\mathbf{5 3}$ according to ${ }^{1} \mathrm{H}$ NMR spectra at various temperatures. The molecular structure of the nitrosyl salt $\mathbf{5 3}$ appears in Figure 2. The ORTEP drawing reveals an endo conformation, i.e., the allyl mouth faces the cyclopentadienyl group; the nitrosyl group is trans to the $\mathrm{CH}_{2}$ terminus. Variable-temperature ${ }^{1} \mathrm{H}$ NMR spectra of 54 (supporting information) in $\mathrm{CD}_{2} \mathrm{Cl}_{2}$ showed the presence of two species at $30{ }^{\circ} \mathrm{C}$ in a $7 / 1$ ratio, but only one conformer was present in solution at $-40^{\circ} \mathrm{C}$. The minor conformer undergoes rapid conversion to the more stable species at low temperature. The proton NMR patterns of the ring protons of 54 and 55 bear close resemblance to those of $\mathbf{1 8}, \mathbf{1 9}$, and $\mathbf{5 3}$, particularly for the $\mathrm{C}(5)$ methylene protons which appear as $\mathrm{dd}(\mathrm{d}=$ doublet, $J=17,10 \mathrm{~Hz}$ ), and $\mathrm{dt}(\mathrm{t}=$ triplet, $J=17,3-4 \mathrm{~Hz})$ pattern, respectively. Hence we assign the two species to be anti isomers that undergo rapid endo-exo conformational exchange following a $\eta^{3} \rightarrow \eta^{1} \rightarrow \eta^{3}$ process. $^{20}$ The stereochemistries of $\mathbf{5 4}$ and $\mathbf{5 5}$ were deduced from the structures of $\mathbf{5 3}$ as substitution of iodide for the carbonyl group of $\mathbf{5 3}$ proceeded via a retention pathway. ${ }^{20}$ Notably the stereochemistries of $\mathbf{5 4}$ and $\mathbf{5 5}$ differ from that of $\mathrm{CpMo}(\mathrm{NO}) \mathrm{X}\left(\eta^{3}-1-R\right.$-allyl) $(\mathrm{X}=$ halide $),{ }^{17,18}$ which has a nitrosyl cis to the $\mathrm{CH}_{2}$ terminus in an endo conformation. Despite this difference, complexes of these two types undergo diastereoselective addition with aldehydes.

\section{Discussion}

Stereochemical Course of Intramolecular Alkoxycarbonylation. The fact that an $\alpha$-(tert-butyl)dimethylsiloxyl group effects syn stereoselection for formation of tungsten $\eta^{3}-\gamma$ lactones is an interesting issue in organometallic reaction. The reaction mechanism is distinct from those of formation of $\eta^{3}$ $\delta$ - and - $\epsilon$-lactones because the former requires water. The results in Scheme 3 enable us to elucidate the mechanism. Isolation of complex 12 together with an $\mathrm{H}_{2}{ }^{18} \mathrm{O}$ labeling experiment indicate a mechanism in Scheme 11 that involves an intramolecular alkoxycarboxylation via attack of water at the carbonyl group of $\eta^{2}$-allene cation I to yield 12. The most stable configuration of $\mathbf{1 2}$ is attained on arranging its most bulky $\mathrm{OSiMe}_{2}(t-\mathrm{Bu})$ group and allyl carbons in a zigzag conformation

(20) (a) Faller, J. W.; Shvo, Y.; Chao, K.; Murray, H. H. J. Organomet. Chem. 1982, 226, 251. (b) Faller, J. W.; Shvo, Y. J. Am. Chem. Soc. 1980, 102, 5396.

\section{Scheme 11}

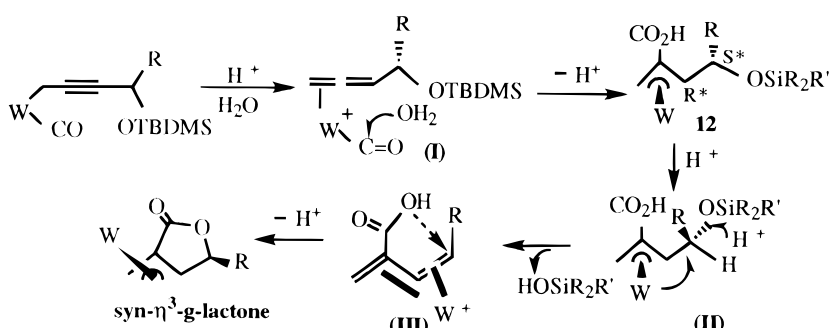

Scheme 12

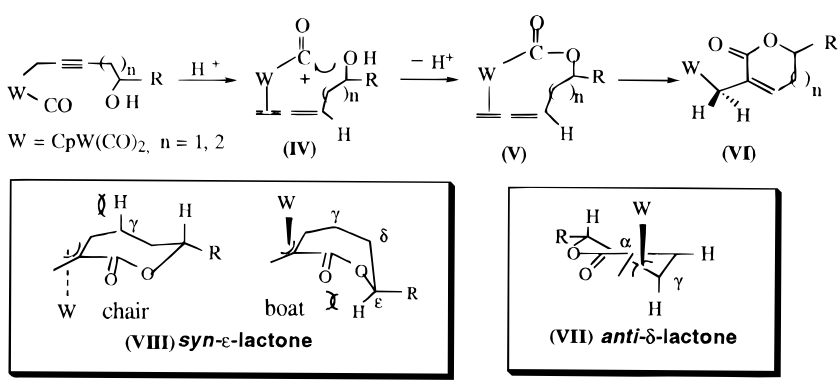

with the R substituent opposite the metal, as represented in $\mathbf{1 2}$. The X-ray structure of optically active complex 14 is significant because it not only confirms the $3 R^{*}, 4 S^{*}$ configuration of $\mathbf{1 2}$ (Scheme 12) but also shows the retention of stereochemistry on substitution of the OTBDMS group by $\mathrm{COOH}$. We propose that in the presence of protons $\mathbf{1 2}$ undergoes intramolecular metal-assisted ionization to yield a cis- $\eta^{4}-s$-trans-diene cation III. $^{21,22}$ In this ionization, the leaving siloxyl group prefers to be opposite the tungsten fragment to facilitate ionization. Subsequent exo attack of $\mathrm{COOH}$ on the $=\mathrm{CR}$ carbon of species III is expected to yield $s y n-\eta^{3}-\gamma$-lactone. Retention of stereochemistry is thus achieved on double inversions of the $\mathrm{C}(4)$ carbon of 12. Such a metal-assisted ionization mechanism has been previously observed for low-valent transition metal complexes. $^{23-25}$

Scheme 12 rationalizes the highly stereselective formation of tungsten $-\eta^{3}-\delta$ - and $-\epsilon$-lactones; the initial step involves intramolecular hydroxyl attack on the $\eta^{2}$-allene cation to yield species V. Subsequent insertion of the WCO group into the central $\eta^{2}$-allene carbon of $\mathbf{V}$ yielded a 16-electron intermediate VI. The $\mathrm{W}-\mathrm{CH}_{2} \sigma$ bond of $\mathbf{V I}$ is parallel to the $\mathrm{C}_{\alpha}-\mathrm{CO}$ bond to follow cis insertion. Therefore, the ultimate control of the stereoselectivity of $\eta^{3}-\delta$ - and $-\epsilon$ lactones depends on direction of rotation of the $\mathrm{WCH}_{2}-\mathrm{C}_{\alpha}$ bond of VI to form the most stable $\pi$-allyl complex. Corresponding to VI are the two states VII and VIII that show conformational effects of six- and sevenmembered rings on $\pi$-allyl formation. State VII has a chairlike conformation with $\mathrm{R}$ in a pseudoequatorial position. A preferable anti configuration is generated on rotating the $\mathrm{WCH}_{2}-\mathrm{C}_{\alpha}$ $\sigma$ bond away from the axial $\mathrm{C}_{\gamma} \mathrm{H}$ axial hydrogen. State VIII represents a twisted boat or chair conformation for $\epsilon$-lactones. In the former, the formation of anti isomer is prohibited by a direct confrontation between $\mathrm{CpW}(\mathrm{CO})_{2}$ and the axial $\mathrm{C}_{\epsilon} \mathrm{H}$ bond.

(21) (a) Erker, G.; Wicker, J.; Engel, K.; Rosenfeldt, F.; Dietrich, W.; Kruger, C. J. Am. Chem. Soc. 1980, 102, 6344. (b) Nakamura, A.; Yasuda, H. Angew. Chem., Int. Ed. Engl. 1987, 26, 723.

(22) Benyunes, S. A.; Green, M.; Grimshire, M. J. Organometallics 1989, $8,2268$.

(23) (a) Little, W. F.; Lynam, K. W.; Williams, R., J. Am. Chem. Soc. 1964, 86, 3055. (b) Beckwich, A. L. J.; Leydon, R. J., J. Am. Chem. Soc. 1964, 86, 953. (c) Trifan, D. S.; Nicholas, L. J. Am. Chem. Soc. 1957, 79, 2746.

(24) Gree, R. Syntheses 1989, 341.

(25) Vong, W.-J.; Peng, S. -M.; Lin, S.-H.; Lin, W.-J.; Liu, R.-S. J. Am. Chem. Soc. 1991, 113, 573. 


\section{Scheme 13}

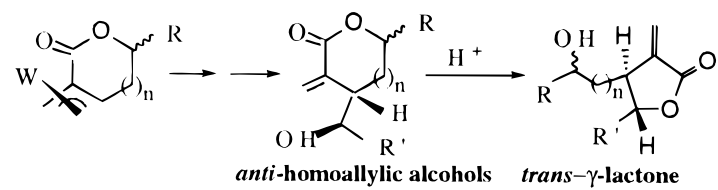

Scheme 14

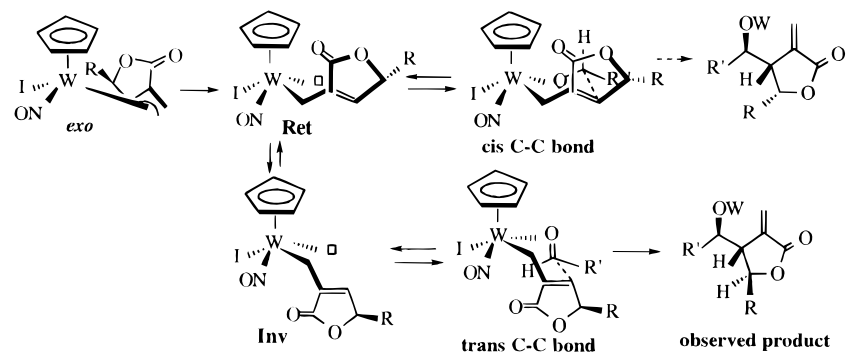

The chair conformation also leads to the same stereoselection because generation of anti isomer is hindered by the steric effect of the axial $\mathrm{C}_{\gamma}-\mathrm{H}$ bond.

Stereochemical Course of Synthesis of Complex $\alpha$-Methylene Lactones. A $\mathrm{CpW}(\mathrm{CO})_{2}\left(\eta^{3}\right.$-lactonyl) compound is a convenient source for stereoselective syntheses of complex $\alpha$-methylene lactones; the operation is best performed in a single step to achieve maximum yields. Although many transition metal $\pi$-allyl compounds function as allyl anions, ${ }^{26-30}$ because of the simplicity of allyl structure, few are suitable for stereoselective synthesis of complex acyclic homoallylic alcohols. Although three stereogenic carbons are created in the reaction; structural analyses of the resulting products reveal that all have a common anti configuration at the subunit of the homoallylic alcohol as shown in Scheme 13. Proton-catalyzed trans esterification of this functionalty gave trans- $\alpha$-methylene butyrolactones; hence a cyclic transition state controls the stereochemistry. ${ }^{17,18}$

Additions of aldehydes and ketones to tungsten $-\eta^{3}-\gamma$ - and $-\delta$-lactones preferentially proceed from the opposite face relative to the metal fragment. We first rationalize this inversion of stereochemistry with a plausible mechanism (Scheme 14). According to the structures of $\mathbf{5 4}$ and 55 (Scheme 10), the $\pi$-allyl carbon terminus trans to NO is prone to dissociation ${ }^{17,18}$ to leave a coordination site to give Ret (retention of conformation); in this manner, the active species is exo conformer rather

(26) For a comprehensive review in the electrophilic alkylations of metal-allyl complexes, see: Yamamoto, Y.; Asao, N. Chem. Rev. 1993, 93, 2207.

(27) For representative examples of nickel allyl complexes, see: (a) (a) Corey, E. J.; Semmelhack, M. F. J. Am. Chem. Soc. 1967, 92, 2756. (b) Mackenzie, P. B.; Grisso, B. A.; Johnson, J. R. J. Am. Chem. Soc. 1992, 114, 5160. (c) Johnson, J. R.; Tully, P. S.; Mackenize, P. B.; Sabat, M. J. Am. Chem. Soc. 1991, 113, 6172.

(28) Titanium allyl complexes, see: (a) Kobayashi, Y.; Umeyama, K.; Sato, F. J. Chem. Soc., Chem. Commun. 1984, 621. (b) Sato, F.; Uchiyama, H.; Iida, K.; Kobayashi, Y.; Sato, M. J. Chem. Soc., Chem. Commun. 1983, 921. (c) Sato, F,; Iijima, S.; Sato, M. Tetrahedron Lett. 1981, 22, 243. (d) Sato, F.; Suzuki, Y.; Sato, M. Tetrahedron Lett. 1982, 23, 4589. (e) Collins, S.; Dean, W. P.; Ward, D. G. Organometallics 1988, 7, 2289. (f) Collins, S.; Kuntz, B. A.; Hong, Y. J. Org. Chem. 1989, 54, 4154.

(29) Iron and ruthenium allyl complexes. See: (a) Itoh, K.; Nakanishi, S.; Otsuji, Y. J. Organomet. Chem. 1994, 473, 215. (b) Kondo, T; Ono, H.; Satake, N,; Mitsudo, T,-A.; Watanabe, Y. Organometallics 1995, 14, 1945.

(30) Palladium allyl complexes. See: (a) Trost, B. M.; Herndon, J. W. J. Am. Chem. Soc. 1984, 106, 6835. (b) Masuyama, Y.; Kinugawa, N.; Kurusu, Y. J. Org. Chem. 1987, 52, 3702. (c) Takahara, J. P.; Masuyama, Y.; Kurusu, Y. J. Am. Chem. Soc. 1992, 114, 2577. (d) Trost, B. M.; Tometzki, G. B. J Org. Chem. 1988, 53, 915. (e) Tabuchi, T.; Inanaga, J.; Yamaguchi, M. Tetrahedron Lett. 1987, 28, 215. (f) Tabuchi, T.; Inanaga, J.; Yamaguchi, M. Tetrahedron Lett. 1986, 27, 1195.

\section{Scheme 15}
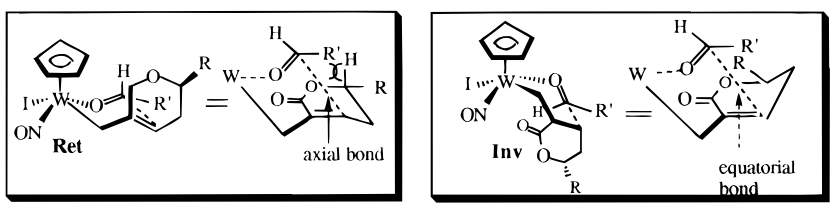

Scheme 16
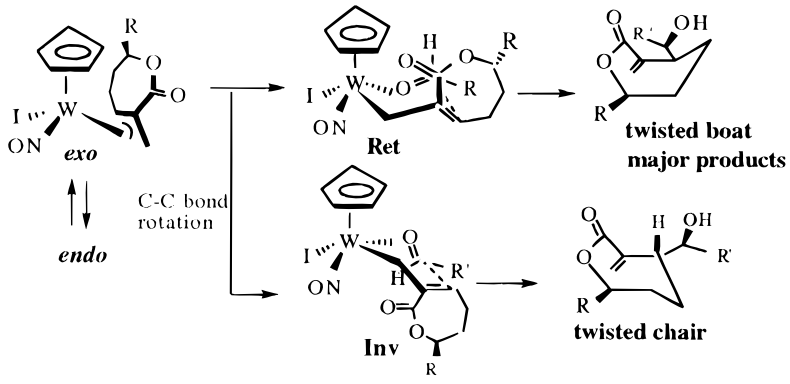

than endo conformer. Coordination of the aldehyde to Ret forms a chairlike conformation in which the $\mathrm{R}^{\prime}$ substituent of the aldehyde is located in an equatorial position to minimize steric hindrance. Generation of the carbon-carbon bond in this transition state, however, suffers from a cis 1,2-steric interaction with lactone $\mathrm{R}$ substituent. Therefore we propose that rotation of the carbon-carbon bond of Ret produces a new transition state Inv (inversion of conformation) in which formation of the trans carbon-carbon bond proceeds more feasibly than that in Ret. The $\alpha$-methylene butyrolacyones given by Inv are consistent with the observed products in Scheme 5.

According to this late transition-state hypothesis, as shown in Scheme 15, the exo isomer of $\mathbf{5 6}$ generates two transition states Ret and Inv in which addition of aldehydes the allyl C(3) carbon proceeds on the same or opposite metal face, respectively. If a $\delta$-lactonyl $\mathrm{R}$ substituent is a bulky phenyl group, Ret becomes less favorable because the forming carbon-carbon bond suffers a 1,3-axial steric hindrance. In contrast, carbonyl addition in Inv proceeds more feasibly than that in Ret because the forming carbon-carbon bond is situated in a less hindered equatorial position; the resulting products from Inv have the same structures as those in Scheme 8.

The mechanisms above show that the key transition states bear productlike structures to determine stereoselection of $\alpha$-methylene $\gamma$ - and $\delta$-lactone products. Addition of organic carbonyls to tungsten $-\eta^{3}-\epsilon$-lactones occurs from the same side as the tungsten fragment, indicating a kinetic influence. As shown in Scheme 16, the cis and trans diastereomeric products are of comparable energy, ${ }^{31}$ shown by their representative twisted boat and chair conformations. Both structures have the four $\mathrm{sp}^{3}$-hybridized carbons in mutually staggered conformations, as well as the alkyl substituents in less hindered equatorial positions. Therefore, formation of carbon-carbon bonds in these two structures occurs at equal rates. In an overall reaction, state Ret however becomes more important than Inv because generation of the latter requires an additional energy on rotation of the $\sigma \mathrm{C}-\mathrm{C}$ bond of Ret.

\section{Conclusion}

In this work, two tungsten-mediated stereocontrolled reactions are described, and the stereochemistries and reaction mechanisms are discussed in detail. The two reactions effect stereoselective transformation of chloroalkynols to $\beta$-(hydroxylalkyl)-

(31) Bocian, D. F.; Pickett, H. M.; Rounds, T. C.; Strauss, H. L., J. Am. Chem Soc. 1975, 97, 687. 
$\alpha$-methylene butyrolactones efficiently. As starting materials chloroalkynols are readily prepared in chiral forms, we prepared two chiral $\alpha$-methylene butyrolactones according to our new methods. In principle, these $\alpha$-methylene butyrolactones make accessible 1,3-1,4-, and 1,5-diols, as well as pyrans and furans upon ring opening of lactones. In accordance with this speculations, we provide a specific instance of conversion of $\beta$-(2'-hydroxypentyl)- $\alpha$-methylene butyrolactone to a trisubstituted 1,5-diol and pyran.

\section{Experimental Section}

Unless otherwise noted, all reactions were carried out under a nitrogen atmosphere in oven-dried glassware using standard syringe, cannula, and septa apparatus. Benzene, diethyl ether, tetrahydrofuran, and hexane were dried with sodium benzophenone and distilled before use. Dichloromethane was dried over $\mathrm{CaH}_{2}$ and distilled before use. $\mathrm{W}(\mathrm{CO})_{6}, \mathrm{BF}_{3} \cdot \mathrm{Et}_{2} \mathrm{O}$, dicyclopentadiene, propargyl alcohol, and sodium were obtained commercially and used without purification. Organic substrates $\mathbf{1 - 7},{ }^{11} \mathbf{1 3}-\mathbf{1 7},{ }^{11} \mathbf{2 2}-\mathbf{2 3},{ }^{11}$ and $\mathbf{2 6}{ }^{11}$ were prepared according to literature reports. Syntheses and spectral data of compounds of the same family 9-11, 19, 20, 25, 27, 30-35, 37, 40-42, and 44-48 in the repetitive operations are listed in supporting information.

Elemental analyses were performed at National Cheng Kung University, Taiwan. Mass data of tungsten and rhenium compounds were reported according to ${ }^{184} \mathrm{~W}$ and ${ }^{187} \mathrm{Re}$ isotopes.

(1) General Procedure for Synthesis of $\mathrm{CpW}(\mathrm{CO})_{2}\left(\eta^{3}-\gamma\right.$-Lactonyl) Compounds. Synthesis of 8. In a typical reaction, to a THF solution $(100 \mathrm{~mL})$ of $\mathrm{CpW}(\mathrm{CO})_{3} \mathrm{Na}(\sim 11.0 \mathrm{mmol})$ was slowly added 6-chlorohex-4-yn-3-ol (1; $1.46 \mathrm{~g}, 11.0 \mathrm{mmol})$ in THF $(5 \mathrm{~mL})$; the mixture was stirred for $5 \mathrm{~h}$ at $23^{\circ} \mathrm{C}$. The solution was evaporated to dryness, and the resulting $\eta^{1}$-propargyl complex was chromatographed over a short alumina column under medium pressure. To this compound (4.57 $\mathrm{g}, 10.6 \mathrm{mmol})$ in cold $\mathrm{CH}_{2} \mathrm{Cl}_{2}\left(20 \mathrm{~mL},-40{ }^{\circ} \mathrm{C}\right)$ was slowly added $\mathrm{CF}_{3} \mathrm{SO}_{3} \mathrm{H}(0.22 \mathrm{~mL}, 2.50 \mathrm{mmol})$, and the mixture was stirred for $1 \mathrm{~h}$ before the temperature was raised to $0{ }^{\circ} \mathrm{C}$. To the solution was added a saturated $\mathrm{NaHCO}_{3}$ solution, followed by evaporation to half volume. The organic layer was extracted with diethyl ether $(2 \times 20 \mathrm{~mL})$, concentrated, and eluted through a silica column (diethyl ether/hexane $=1 / 1)$ to give a yellow band of $\mathbf{8}\left(R_{f}=0.56,3.64 \mathrm{~g}, 8.48 \mathrm{mmol}\right.$, 80\%): IR (Nujol, $\left.\mathrm{cm}^{-1}\right) v(\mathrm{CO}) 1950(\mathrm{~s}), 1867(\mathrm{~s}), 1750(\mathrm{~m})$. Syn isomer (71\%): ${ }^{1} \mathrm{H}$ NMR $\left(400 \mathrm{MHz}, \mathrm{C}_{6} \mathrm{D}_{6}\right) \delta .4 .65(5 \mathrm{H}, \mathrm{s}), 4.21(1 \mathrm{H}, \mathrm{dt}, J=$ $4.1,2.5 \mathrm{~Hz}), 3.00(1 \mathrm{H}, \mathrm{d}, J=3.0 \mathrm{~Hz}), 2.94(1 \mathrm{H}, \mathrm{d}, J=2.0 \mathrm{~Hz}), 1.34$ $(1 \mathrm{H}, \mathrm{dq}, J=5.6,4.1 \mathrm{~Hz}), 1.26(1 \mathrm{H}, \mathrm{d}, J=2.0 \mathrm{~Hz}), 1.15(1 \mathrm{H}, \mathrm{dq}, J=$ $5.6,4.1 \mathrm{~Hz}), 0.89(3 \mathrm{H}, \mathrm{t}, J=5.6 \mathrm{~Hz}) ;{ }^{13} \mathrm{C} \mathrm{NMR}\left(100 \mathrm{MHz}, \mathrm{C}_{6} \mathrm{D}_{6}\right)$ d.225.7, 220.6, 174.8, 93.4, 81.9, 70.4, 70.1 , 32.2, 19.7, 10.7. Anti isomer (29\%): ${ }^{1} \mathrm{H}$ NMR (400 MHz, $\left.\mathrm{C}_{6} \mathrm{D}_{6}\right) \delta 4.69(5 \mathrm{H}, \mathrm{s}), 4.14(1 \mathrm{H}, \mathrm{t}$, $J=6.0 \mathrm{~Hz}), 3.00(1 \mathrm{H}, \mathrm{d}, J=2.4 \mathrm{~Hz}), 2.83(1 \mathrm{H}, \mathrm{s}), 1.35(2 \mathrm{H}, \mathrm{dq}, J=$ $7.1,6.0 \mathrm{~Hz}), 1.30(1 \mathrm{H}, \mathrm{d}, J=2.4 \mathrm{~Hz}), 0.74(3 \mathrm{H}, \mathrm{t}, J=7.1 \mathrm{~Hz}) ;{ }^{13} \mathrm{C}$ NMR (100 MHz, $\left.\mathrm{C}_{6} \mathrm{D}_{6}, 298 \mathrm{~K}\right) \delta 226.4,220.2,175.1,93.8,84.4,69.5$, 66.9, 30.9, 21.2, 8.6; MS (EI, $12 \mathrm{eV}, \mathrm{m} / \mathrm{e}) 430\left(\mathrm{M}^{+}\right)$. Anal. Calcd for $\mathrm{C}_{14} \mathrm{H}_{14} \mathrm{WO}_{4}$ : C, 39.10; H, 3.28. Found: C, 39.02; H, 3.29.

(2) Synthesis of $\left(3 R^{*}, 4 S^{*}\right)$-CpW(CO) 2 (2-Carboxylic acid-4-[(tertbutyl) dimethylsiloxyl]-5-methyl-2-hexen-1-yl) (12). This compound was similarly prepared from 1-chloro-4-[(t-butyl)dimethylsiloxyl]-2hexyne $(1.50 \mathrm{~g}, 5.74 \mathrm{mmol})$ and $\mathrm{CpW}(\mathrm{CO})_{3} \mathrm{Na}(5.50 \mathrm{mmol})$ except that $\mathrm{CF}_{3} \mathrm{CO}_{2} \mathrm{H}(0.10 \mathrm{~mL}, 1.20 \mathrm{mmol})$ and water $(0.20 \mathrm{~mL}, 11 \mathrm{mmol})$ were employed in the reaction; the yield of $\mathbf{1 2}$ was $73 \%(2.39 \mathrm{~g}, 4.16$ mmol): IR (Nujol, $\mathrm{cm}^{-1}$ ) $v(\mathrm{CO}) 1968,1907(\mathrm{vs}), 1659(\mathrm{~s}) ;{ }^{1} \mathrm{H}$ NMR $\left(300 \mathrm{MHz}, \mathrm{CDCl}_{3}\right) \delta 5.29(5 \mathrm{H}, \mathrm{s}), 4.76(1 \mathrm{H}, \mathrm{dd}, J=9.3,2.8 \mathrm{~Hz}), 2.93$ $(1 \mathrm{H}, \mathrm{s}), 2.26(1 \mathrm{H}, \mathrm{d}, J=9.3 \mathrm{~Hz}), 1.98(1 \mathrm{H}, \mathrm{m}), 1.11(1 \mathrm{H}, \mathrm{s}), 0.91(3 \mathrm{H}$, s), $0.90(3 \mathrm{H}, \mathrm{s}), 0.89(15 \mathrm{H}, \mathrm{s}), 0.12(3 \mathrm{H}, \mathrm{s}), 0.10(3 \mathrm{H}, \mathrm{s}) ;{ }^{13} \mathrm{C}$ NMR $(75$ $\left.\mathrm{MHz}, \mathrm{CDCl}_{3}\right) \delta 222.3,222.2,175.6,88.8,75.7,75.5,55.7,37.7,26.3$, 23.1, 18.5, 17.7, 17.4; MS (FAB, m/e) 576. Anal. Calcd for $\mathrm{C}_{21} \mathrm{H}_{32}$ $\mathrm{WSiO}_{5}$ : C, 43.76; H, 5.60; Found: C, 43.72; H, 5.52.

(3) Synthesis of Chiral (+)-CpW(CO) $2\left(\eta^{3}-\gamma\right.$-lactonyl) Complex (14). This optically active compound was similarly prepared from $\mathbf{1 3}$ $(5.00 \mathrm{~g}, 15.7 \mathrm{mmol})$ and $\mathrm{CpW}(\mathrm{CO})_{3} \mathrm{Na}(17.2 \mathrm{mmol})$, followed with acidification with $\mathrm{CF}_{3} \mathrm{SO}_{3} \mathrm{H}(0.34 \mathrm{~mL}, 3.90 \mathrm{mmol})$ and water $(0.28$ $\mathrm{mL}, 15.7 \mathrm{mmol})$. The yield of $\mathbf{1 4}$ was $70 \%$ (5.50 g, $11.0 \mathrm{mmol})$ : IR (Nujol, $\mathrm{cm}^{-1}$ ) $v(\mathrm{CO}) 1957(\mathrm{~s}), 1873(\mathrm{~s}), 1747(\mathrm{~s}) ;{ }^{1} \mathrm{H}$ NMR $(400 \mathrm{MHz}$, $\left.\mathrm{CDCl}_{3}\right) \delta 5.38(5 \mathrm{H}, \mathrm{s}, \mathrm{Cp}), 4.97(1 \mathrm{H}, \mathrm{dd}, J=8.5,3.5 \mathrm{~Hz}), 4.30(1 \mathrm{H}$, $\mathrm{dd}, J=8.7,6.3 \mathrm{~Hz}), 3.96(1 \mathrm{H}, \mathrm{dd}, J=8.7,5.3 \mathrm{~Hz}), 3.68(1 \mathrm{H}, \mathrm{ddd}, J$ $=8.6,6.3,5.3 \mathrm{~Hz}), 3.30(1 \mathrm{H}, \mathrm{d}, J=3.5 \mathrm{~Hz}), 3.12(1 \mathrm{H}, \mathrm{d}, J=3.8$ $\mathrm{Hz}), 1.52(1 \mathrm{H}, \mathrm{d}, J=3.8 \mathrm{~Hz}) ;{ }^{13} \mathrm{C} \mathrm{NMR}\left(100 \mathrm{MHz}, \mathrm{CDCl}_{3}\right) \delta 224.9$, $218.7,170.5,110.7,93.7,81.1,69.7,65.9,62.0,26.6,25.3,20.9$; MS $(12 \mathrm{eV}, \mathrm{m} / \mathrm{e}) 502\left(\mathrm{M}^{+}\right), 474\left(\mathrm{M}^{+}-\mathrm{CO}\right) ;[\alpha]^{24}{ }_{\mathrm{D}}+110.9^{\circ}(c=0.10$, $\mathrm{CH}_{2} \mathrm{Cl}_{2}$ ). Anal. Calcd for $\mathrm{C}_{17} \mathrm{H}_{18} \mathrm{WO}_{6}$ : C, 40.66; H, 3.61. Found: C, 40.48; H, 3.55.

(4) General Procedure for Synthesis of $\mathrm{CpW}(\mathrm{CO})_{2}\left(\eta^{3}-\delta\right.$-Lactonyl Compounds. Synthesis of 18 . This compound was similarly prepared from 7-chloro-3-hydroxy-5-heptyne (15; $5.00 \mathrm{~g}, 34.2 \mathrm{mmol})$ and $\mathrm{CpW}$ $(\mathrm{CO})_{3} \mathrm{Na}(37.7 \mathrm{mmol})$ in $\mathrm{CH}_{2} \mathrm{Cl}_{2}$, followed by acidification with $\mathrm{CF}_{3}$ $\mathrm{SO}_{3} \mathrm{H}(0.45 \mathrm{~mL}, 5.13 \mathrm{mmol})$ at $-40{ }^{\circ} \mathrm{C}$; the yield of $\mathbf{1 8}$ was $82 \%(12.5$ $\mathrm{g}, 28.0 \mathrm{mmol}$ ): IR (Nujol, $\left.\mathrm{cm}^{-1}\right) v(\mathrm{CO})$ 1946(s), 1868(s), 1703(s); ${ }^{1} \mathrm{H}$ $\operatorname{NMR}\left(300 \mathrm{MHz}, \mathrm{C}_{6} \mathrm{D}_{6}\right) \delta 4.66(\mathrm{~s}, 5 \mathrm{H}), 3.35(1 \mathrm{H}, \mathrm{m}), 2.70(1 \mathrm{H}, \mathrm{d}, J=$ $2.2 \mathrm{~Hz}), 2.13(1 \mathrm{H}, \mathrm{dt}, J=16.2,3.3 \mathrm{~Hz}), 1.96(1 \mathrm{H}, \mathrm{d}, J=3.0 . \mathrm{Hz})$, $1.82(1 \mathrm{H}, \mathrm{ddd}, J=16.2,10.0 \mathrm{~Hz}), 1.44(1 \mathrm{H}, \mathrm{m}), 1.29(1 \mathrm{H}, \mathrm{m}), 0.78$ $(3 \mathrm{H}, \mathrm{t}, J=7.4 \mathrm{~Hz}), 0.66(1 \mathrm{H}, \mathrm{d}, J=2.2 \mathrm{~Hz}) ;{ }^{13} \mathrm{C}$ NMR $(300 \mathrm{MHz}$, $\left.\mathrm{C}_{6} \mathrm{D}_{6}\right) \delta 225.5,217.7,170.4,91.9,78.0,61.8,61.7,30.1,28.2,19.6$, 9.8; MS (EI, m/e) $444\left(\mathrm{M}^{+}\right)$. Anal. Calcd for $\mathrm{C}_{15} \mathrm{H}_{16} \mathrm{WO}_{4}$ : C, 40.57; H, 3.36. Found: C, 40.49; H, 3.63 .

(5) Demetalation of 19. To 19 (0.25 g, $0.51 \mathrm{mmol})$ in $\mathrm{CH}_{3} \mathrm{CN}$ (2 $\mathrm{mL})$ was added $\mathrm{NOBF}_{4}(58.9 \mathrm{mg}, 0.51 \mathrm{mmol})$ at $0{ }^{\circ} \mathrm{C}$, and the mixture was stirred for $1 \mathrm{~h}$ before addition of $\mathrm{Bu}_{4} \mathrm{NBH}_{4}(0.16 \mathrm{~g}, 0.61 \mathrm{mmol})$. After stirring for $1 \mathrm{~h}$, to the solution was added $\left(\mathrm{NH}_{4}\right)_{2} \mathrm{Ce}\left(\mathrm{NO}_{3}\right)_{6}(0.56$ $\mathrm{g}, 1.02 \mathrm{mmol}$ ) at $0{ }^{\circ} \mathrm{C}$ with stirring for $20 \mathrm{~min}$. The resulting solution was concentrated and chromatographed on a preparative silica TLC (diethyl ether/hexane $=1 / 2)$ to give 21 as an colorless oil $\left(R_{f}=0.58\right.$, $81 \mathrm{mg}, 0.42 \mathrm{mmol}, 86 \%$ yield): IR(Nujol, $\left.\mathrm{cm}^{-1}\right) v(\mathrm{CO}) 1730(\mathrm{~s}), v$ $(\mathrm{C}=\mathrm{C}) 1648(\mathrm{w}) ;{ }^{1} \mathrm{H} \mathrm{NMR}\left(400 \mathrm{MHz}, \mathrm{CDCl}_{3}\right) \delta 7.39-7.30(5 \mathrm{H}, \mathrm{m})$, $6.64(1 \mathrm{H}, \mathrm{dd}, J=5.9,1.8 \mathrm{~Hz}), 5.39(1 \mathrm{H}, \mathrm{dd}, J=10.9,4.2 \mathrm{~Hz}), 2.63$ (1H, ddd, $J=17.6,10.9,1.8 \mathrm{~Hz}), 2.52(1 \mathrm{H}, \mathrm{ddd}, J=17.6,5.9,4.2$ $\mathrm{Hz}), 1.96(3 \mathrm{H}, \mathrm{s}) ;{ }^{13} \mathrm{C}$ NMR $\left(100 \mathrm{MHz}, \mathrm{CDCl}_{3}\right) \delta 165.7,138.7,138.6$, 128.8, 128.5, 128.4, 126.0, 79.3, 32.0, 17.1; MS (EI, $75 \mathrm{eV}, \mathrm{m} / \mathrm{e}) 188$ $\left(\mathrm{M}^{+}\right)$; HRMS calcd for $\mathrm{C}_{12} \mathrm{H}_{12} \mathrm{O}_{2} 188.0837\left(\mathrm{M}^{+}\right)$, found 188.0829.

(6) General Procedure for Synthesis of $\mathrm{CpW}(\mathrm{CO})_{2}\left(\eta^{3}-\epsilon-\right.$ Lactonyl $)$ Compounds. Synthesis of 24. This compound was similarly prepared from 7-chlorohept-5-yn-2-ol (2.31 g, $15.7 \mathrm{mmol})$ and $\mathrm{CpW}(\mathrm{CO})_{3} \mathrm{Na}$ (17.3 mmol) in $\mathrm{CH}_{2} \mathrm{Cl}_{2}$, followed by acidification with $\mathrm{CF}_{3} \mathrm{SO}_{3} \mathrm{H}(0.23$ $\mathrm{mL}, 2.60 \mathrm{mmol})$ at $-40{ }^{\circ} \mathrm{C}$; the yield of 24 was $80 \%(5.60 \mathrm{~g}, 12.6$ mmol): IR (Nujol, $\mathrm{cm}^{-1}$ ) $v(\mathrm{CO}) 1953(\mathrm{~s}), 1872(\mathrm{~s}), 1711(\mathrm{~s}) ;{ }^{1} \mathrm{H}$ NMR $\left(400 \mathrm{MHz}, \mathrm{CD}_{2} \mathrm{Cl}_{2},-30{ }^{\circ} \mathrm{C}\right)$ exo isomer, $\delta 5.50(5 \mathrm{H}, \mathrm{s}), 5.12(1 \mathrm{H}, \mathrm{m})$, $2.91(1 \mathrm{H}, \mathrm{d}, J=1.8 \mathrm{~Hz}), 2.38(1 \mathrm{H}, \mathrm{m}), 1,94(1 \mathrm{H}, \mathrm{m}), 1.78-1.72(\mathrm{~m}$, $2 \mathrm{H}), 1.57(1 \mathrm{H}, \mathrm{m}), 1.47(3 \mathrm{H}, \mathrm{d}, J=6.0 \mathrm{~Hz}), 1.17(1 \mathrm{H}, \mathrm{d}, J=1.8 \mathrm{~Hz})$; endo isomer, $\delta 5.32(5 \mathrm{H}, \mathrm{s}), 5.04(1 \mathrm{H}, \mathrm{m}), 2.97(1 \mathrm{H}, \mathrm{s}), 2.50(1 \mathrm{H}, \mathrm{m})$, $2.24(1 \mathrm{H}, \mathrm{m}), 1.78(1 \mathrm{H}, \mathrm{s}), 1.42(3 \mathrm{H}, \mathrm{d}, J=7.2 \mathrm{~Hz})$, the rest signals were masked by signals of the exo isomer in the region $\delta 1.78-1.72$ ppm; ${ }^{13} \mathrm{C}$ NMR $\left(100 \mathrm{MHz}, \mathrm{CD}_{2} \mathrm{Cl}_{2}, 243 \mathrm{~K}\right)$ exo conformer, $\delta 224.5$, 220.8, 176.6, 94.8, 76.8, 69.3, 51.4, 37.7, 31.4, 26.2, 21.0; endo conformer $\delta$ 226.8, 225.0, 174.2, 89.3, 88.1, 76.1, 41.9 , 38.2, 33.4, 31.3, 21.0; MS (EI, $12 \mathrm{eV}, \mathrm{m} / \mathrm{e}$ ): $444\left(\mathrm{M}^{+}\right)$. Anal. Calcd for $\mathrm{C}_{15} \mathrm{H}_{16^{-}}$ $\mathrm{WO}_{4}, 40.57$; H, 3.63. Found: C, 40.47; H, 3.71 .

(7) Demetalation of 27. To $27(0.56 \mathrm{~g}, 1.16 \mathrm{mmol})$ in $\mathrm{CH}_{3} \mathrm{CN}$ (2 $\mathrm{mL})$ was added $\mathrm{NOBF}_{4}(1.34 \mathrm{~g}, 1.16 \mathrm{mmol})$ at $0{ }^{\circ} \mathrm{C}$; the mixture was stirred for $20 \mathrm{~min}$ before addition of $\mathrm{Bu}_{4} \mathrm{NBH}_{4}(0.36 \mathrm{~g}, 1.39 \mathrm{mmol})$. After stirring for $1 \mathrm{~h}$, to the solution was added $\left(\mathrm{NH}_{4}\right)_{2} \mathrm{Ce}\left(\mathrm{NO}_{3}\right)_{6}(1.27$ $\mathrm{g}, 2.32 \mathrm{mmol}$ ) at $0{ }^{\circ} \mathrm{C}$ with stirring for $20 \mathrm{~min}$. The resulting solution was concentrated and chromatographed on a preparative silica TLC (diethyl ether/hexane $=1 / 2)$ to give 28 as an colorless oil $\left(R_{f}=0.56\right.$, $186 \mathrm{mg}, 1.05 \mathrm{mmol}, 91 \%$ yield): IR(Nujol, $\left.\mathrm{cm}^{-1}\right) v(\mathrm{CO}) 1730(\mathrm{~s}), v$ $(\mathrm{C}=\mathrm{C}) 1648(\mathrm{w}) ;{ }^{1} \mathrm{H} \mathrm{NMR}\left(400 \mathrm{MHz}, \mathrm{CDCl}_{3}, 25^{\circ} \mathrm{C}\right) \delta, 6.12(1 \mathrm{H}, \mathrm{br}$ $\mathrm{t}, J=6.0 \mathrm{~Hz}), 3.96(1 \mathrm{H}, \mathrm{td}, J=11.2,4.0 \mathrm{~Hz}), 2.58(1 \mathrm{H}, \mathrm{m}), 2.05$ $(1 \mathrm{H}, \mathrm{m}), 1.94(3 \mathrm{H}, \mathrm{s}), 1.88(1 \mathrm{H}, \mathrm{m}), 1.80(1 \mathrm{H}, \mathrm{m}), 1.56-1.64(4 \mathrm{H}, \mathrm{m})$, $1.18-1.23(3 \mathrm{H}, \mathrm{m}) ;{ }^{13} \mathrm{C} \mathrm{NMR}\left(100 \mathrm{MHz}, \mathrm{CDCl}_{3}\right) \delta, 171,132.0130 .3$, 80.0, 42.0, 31.6, 30.4, 29.5, 24.2, 23.4, 18.5; HRMS calcd for $\mathrm{C}_{11} \mathrm{H}_{16} \mathrm{O}_{2}$ 180.1150 , found 180.1152 .

(8) General Procedure for Condensation of $\mathrm{CpW}(\mathrm{CO})_{2}\left(\eta^{3}-\gamma-\right.$ Lactonyl) with Organic Carbonyls. Synthesis of $\left(4 R^{*}, 5 S^{*}\right)$-[5Methyl-4-[(1 $\left.R^{*}\right)$-1-hydroxy-2-methylpropyl]-3-methylenedihydrofuran-2-one] (29). To a stirring $\mathrm{CH}_{3} \mathrm{CN}(3 \mathrm{~mL})$ of solution 11 (syn isomer) $(1.00 \mathrm{~g}, 2.40 \mathrm{mmol})$ was slowly added a $\mathrm{CH}_{3} \mathrm{CN}$ solution of $\mathrm{NOBF}_{4}(0.31 \mathrm{~g}, 2.64 \mathrm{mmol})$ at $0{ }^{\circ} \mathrm{C}$; after $30 \mathrm{~min}, \mathrm{NaI}(0.72 \mathrm{~g}, 4.80$ $\mathrm{mmol}$ ) was added to the solution. The mixture was stirred for $30 \mathrm{~min}$ 
and then treated with $i$-BuCHO $(0.65 \mathrm{~g}, 7.20 \mathrm{mmol})$ at $0{ }^{\circ} \mathrm{C}$. The solution was warmed to $23{ }^{\circ} \mathrm{C}$ and stirred for $4 \mathrm{~h}$ to produce a dark orange precipitate. The solution was treated with $\mathrm{NaHCO}_{3}(2 \mathrm{~mL})$, concentrated, and eluted on a preparative TLC plate (diethyl ether/ hexane $=1 / 1)$ to give 29 as an oil $\left(R_{f}=0.56,0.32 \mathrm{~g}, 1.56 \mathrm{mmol}\right.$, 65\%): IR (neat, $\mathrm{cm}^{-1}$ ) 3437, 1750, 1652; ${ }^{1} \mathrm{H} \mathrm{NMR}\left(300 \mathrm{MHz}, \mathrm{CDCl}_{3}\right)$ $\delta 6.35(1 \mathrm{H}, \mathrm{d}, J=2.2 \mathrm{~Hz}), 5.76(1 \mathrm{H}, \mathrm{d}, J=2.2 \mathrm{~Hz}), 4.48(1 \mathrm{H}, \mathrm{qd}, J$ $=6.5,3.2 \mathrm{~Hz}), 3.28(1 \mathrm{H}, \mathrm{t}, J=7.6 \mathrm{~Hz}), 2.76(1 \mathrm{H}, \mathrm{m}), 1.78(1 \mathrm{H}, \mathrm{m})$, $1.35(3 \mathrm{H}, \mathrm{d}, J=6.5 \mathrm{~Hz}), 0.99,0.96(3 \mathrm{H}, \mathrm{d}, J=6.5 \mathrm{~Hz}) ;{ }^{13} \mathrm{C} \mathrm{NMR}$ $\left(75 \mathrm{MHz}, \mathrm{CDCl}_{3}\right) \delta$ 170.2. 135.6, 125.1, 77.1, 49.2, 21.9, 19.9, 16.7, MS $(75 \mathrm{eV}, m / e) 185\left(\mathrm{M}^{+}\right)$, HRMS calcd for $\mathrm{C}_{10} \mathrm{H}_{16} \mathrm{O}_{3} 184.1099$, found 184.1192.

(9) Trans Esterfication of 29. To a $\mathrm{CH}_{2} \mathrm{Cl}_{2}$ solution (1 mL) of 29 $(0.51 \mathrm{~g}, 2.51 \mathrm{mmol})$ was added $p$-TSA $(67.2 \mathrm{mg}, 0.50 \mathrm{mmol})$; the mixture was stirred for 4 days before addition of $\mathrm{NaHCO}_{3}$ solution. The solution was concentrated and eluted on a preparative TLC plate (diethyl ether/hexane $=1 / 1)$ to yield a new band of $29 \mathrm{t}\left(R_{f}=0.52\right.$, $291 \mathrm{mg}, 1.43 \mathrm{mmol}, 57 \%$ ): IR (neat, $\mathrm{cm}^{-1}$ ): 3438(br), 1750(s), 1658(m), 1467(m); ${ }^{1} \mathrm{H}$ NMR (400 MHz, $\left.\mathrm{CDCl}_{3}\right) \delta 6.29(1 \mathrm{H}, \mathrm{d}, J=2.1$ $\mathrm{Hz}), 5.69(1 \mathrm{H} \mathrm{d}, J=1.9 \mathrm{~Hz}), 4.21(1 \mathrm{H}, \mathrm{dd}, J=5.6,2.3 \mathrm{~Hz}), 3.82$ $(1 \mathrm{H}, \mathrm{t}, J=6.3 \mathrm{~Hz}), 2.79(1 \mathrm{H}, \mathrm{m}), 1.80(1 \mathrm{H}, \mathrm{m}), 1.18(3 \mathrm{H}, \mathrm{d}, J=6.3$ $\mathrm{Hz}), 0.91(3 \mathrm{H}, \mathrm{d}, J=5.0 \mathrm{~Hz}), 0.90(3 \mathrm{H}, \mathrm{d}, J=5.0 \mathrm{~Hz}) ;{ }^{13} \mathrm{C} \mathrm{NMR}$ $\left(100 \mathrm{MHz}, \mathrm{CDCl}_{3}\right) \delta 170.5,136.0,124.2,84.2,69.2,48.5,33.2,19.4$, 18.6, 16.8; MS (75ev, m/e) $184\left(\mathrm{M}^{+}\right), 140,125 ; \mathrm{HRMS} \mathrm{C}_{10} \mathrm{H}_{16} \mathrm{O}_{3}$ calcd 184.1099, found 184.1103.

(10) Trans Esterfication of 30. To a THF solution $(5 \mathrm{~mL})$ of $\mathbf{3 0}$ (265 mg, $1.25 \mathrm{mmol})$ was added $\mathrm{Cs}_{2} \mathrm{CO}_{3}(0.82 \mathrm{~g}, 2.50 \mathrm{mmol})$; the mixture was heated for $4 \mathrm{~h}$. The solution was concentrated and eluted through a short silica column to yield a $1 / 1$ mixture of $\mathbf{3 0}$ and $\mathbf{3 0 t}$. Spectral data for 30t: IR (neat, $\mathrm{cm}^{-1}$ ) 3433(br), 1752(s), 1653(m), $1467-$ (m); ${ }^{1} \mathrm{H} \mathrm{NMR}\left(400 \mathrm{MHz}, \mathrm{CDCl}_{3}\right) \delta 6.33(1 \mathrm{H}, \mathrm{d}, J=1.5 \mathrm{~Hz}), 5.72$ $(1 \mathrm{H}, \mathrm{d}, J=1.5 \mathrm{~Hz}), 4.47(1 \mathrm{H}, \mathrm{td}, J=7.4,3.5 \mathrm{~Hz}), 3.53(1 \mathrm{H}, \mathrm{ddd}, J$ $=9.3,7.6,4.0 \mathrm{~Hz}), 2.67(1 \mathrm{H}, \mathrm{dd}, J=7.6,3.5 \mathrm{~Hz}), 1.80(1 \mathrm{H}, \mathrm{m}), 1.60$ $(2 \mathrm{H}, \mathrm{m}), 1.55-1.41(2 \mathrm{H}, \mathrm{m}), 0.85-0.98(9 \mathrm{H}, \mathrm{m}) ;{ }^{13} \mathrm{C} \mathrm{NMR}(100 \mathrm{MHz}$, $\left.\mathrm{CDCl}_{3}\right) \delta 170.0,136.1,124.2,78.6,74.5,50.8,46.3,26.7,24.8,23.0$, 21.9, 10.1; HRMS $\mathrm{C}_{12} \mathrm{H}_{20} \mathrm{O}_{3}$ calcd 212.1412, found 212.1416.

(11) Synthesis of $(-)-(4 S, 5 R)-[5-[(4 R)-(2,2-D i m e t h y l[1,3]$ dioxolan4-yl]-4-[(1R)-1-hydroxy-1-phenylmethyl]-3-methylenedihydrofuran2-one] (36). This compound was similarly prepared from chiral tungsten-allyl 14 (0.20 g, $0.39 \mathrm{mmol}), \mathrm{NOBF}_{4}(51 \mathrm{mg}, 0.43 \mathrm{mmol})$, and $\mathrm{NaI}(120 \mathrm{mg}, 0.78 \mathrm{mmol})$ and finally treated with benzaldehyde (85 mg, $0.78 \mathrm{mmol}$ ) at $23{ }^{\circ} \mathrm{C}$ to yield $36(67 \mathrm{mg}, 0.20 \mathrm{mmol}, 50 \%)$ as a colorless oil: IR (neat, $\mathrm{cm}^{-1}$ ) 3465(br s), 1747(s), 1667(m); ${ }^{1} \mathrm{H}$ NMR $\left(400 \mathrm{MHz}, \mathrm{CDCl}_{3}\right) \delta 7.39-7.29(5 \mathrm{H}, \mathrm{m}), 6.30(1 \mathrm{H}, \mathrm{d}, J=2.2 \mathrm{~Hz})$, $5.60(1 \mathrm{H}, \mathrm{d}, J=2.2 \mathrm{~Hz}), 4.73(1 \mathrm{H}, \mathrm{d}, J=7.1 \mathrm{~Hz}), 4.26(1 \mathrm{H}, \mathrm{t}, J=$ 2.0), 3.90-3.70 (3H, m), $3.34(1 \mathrm{H}, \mathrm{dd}, J=7.1,2.0 \mathrm{~Hz}), 1.30(3 \mathrm{H}, \mathrm{s})$, $1.27(3 \mathrm{H}, \mathrm{s}) ;{ }^{13} \mathrm{C}$ NMR $\left(100 \mathrm{MHz}, \mathrm{CDCl}_{3}\right) \delta 170.0,140.3,134.8,128.9$, 128.6, 125.0, 110.6, 76.7, 67.9, 65.0, 48.1, 25.6, 25.3; HRMS calcd for $\mathrm{C}_{17} \mathrm{H}_{20} \mathrm{O}_{5} 304.1310$, found $304.1318 ;[\alpha]^{24}{ }_{\mathrm{D}}-23.04(c=0.76$, $\left.\mathrm{CHCl}_{3}\right)$.

(12) General Procedure for Condensation of $\mathrm{CpW}(\mathrm{CO})_{2}\left(\eta^{3}-\delta\right.$ Lactonyl) (19) with Organic Carbonyls. Synthesis of $\left(4 S^{*}, 5 R^{*}\right)$ [4-[(2S*)-2-Hydroxy-2-phenylethyl]-5-methyl-3-methylenedihydrofuran-2-one] (38). This compound was similarly prepared from 19 (0.35 g, $0.71 \mathrm{mmol}), \mathrm{NOBF}_{4}$ (100 mg, $\left.0.85 \mathrm{mmol}\right)$, and NaI (213 mg, $1.42 \mathrm{mmol})$ and finally treated with acetaldehyde $(62.5 \mathrm{mg}, 1.42 \mathrm{mmol})$ at $23{ }^{\circ} \mathrm{C}$ to yield 38 as a colorless oil (107 $\left.\mathrm{mg}, 0.46 \mathrm{mmol}, 65 \%\right)$ : IR (neat, $\mathrm{cm}^{-1}$ ) 3447(br s), 1750(s), 1661(m); ${ }^{1} \mathrm{H} \mathrm{NMR} \mathrm{(300} \mathrm{MHz,} \mathrm{CDCl}_{3}$ ) $\delta 7.37-7.26(5 \mathrm{H}, \mathrm{Ph}), 6.29(1 \mathrm{H}, \mathrm{d}, J=2.3 \mathrm{~Hz}), 5.68(1 \mathrm{H}, \mathrm{d}, J=2.3$ $\mathrm{Hz}), 4.79(1 \mathrm{H}, \mathrm{dd}, J=9.3,4.0 \mathrm{~Hz}), 4.39(1 \mathrm{H}, \mathrm{d}, J=6.2,3.9 \mathrm{~Hz})$, $2.87(1 \mathrm{H}, \mathrm{ddd}, J=7.5,6.8,3.9 \mathrm{~Hz}), 2.01(1 \mathrm{H}, \mathrm{ddd}, J=14.1,9.3,6.8$ $\mathrm{Hz}), 1.83(1 \mathrm{H}, \mathrm{ddd}, J=14.1,7.5,4.0 \mathrm{~Hz}), 1.36(3 \mathrm{H}, \mathrm{d}, J=6.2 \mathrm{~Hz})$; ${ }^{13} \mathrm{C} \mathrm{NMR}\left(75 \mathrm{MHz}, \mathrm{CDCl}_{3}\right) \delta 170.5,144.0,139.2,128.8,128.2,125.6$, 122.9, 80.4, 72.2, 43.9, 43.1, 21.4. MS (75eV m/e) $232\left(\mathrm{M}^{+}\right)$; HRMS calcd for $\mathrm{C}_{14} \mathrm{H}_{16} \mathrm{O}_{3} 232.1099$, found 232.1107 .

(13) Synthesis of $\left(4 S^{*}, 6 S^{*}\right)$-[4-[(1R*)-1-Hydroxypropyl]-3-methylene-6-phenyltetrahydropyran-2-one] $(39)$ and $\left(4 S^{*}, 5 R^{*}\right)$-[5-Ethyl4-[(2S*)-2-hydroxy-2-phenylethyl]-3-methylenedihydrofuran-2one] (39t). These two cpmounds were similarly prepared from sequential treatment of $\mathbf{1 9}$ with $\mathrm{NOBF}_{4}, \mathrm{NaI}$, and propanal in $\mathrm{CD}_{3} \mathrm{CN}$. Separation of crude product on a silica TLC afforded 39 and 39t in 10 and $58 \%$, respectively. Spectral data for 39: IR (neat, $\mathrm{cm}^{-1}$ ) $v(\mathrm{OH})$, 3447(vs), $v(\mathrm{CO}) 1717(\mathrm{~s}) ;{ }^{1} \mathrm{H}$ NMR $\left(300 \mathrm{MHz}, \mathrm{CDCl}_{3}\right) \delta 7.42-7.28$ $(5 \mathrm{H}, \mathrm{m}, \mathrm{Ph}), 6.34\left(1 \mathrm{H}, \mathrm{d}, J=2.0 \mathrm{~Hz}^{\prime}\right), 5.67(1 \mathrm{H}, \mathrm{d}, J=2.0 \mathrm{~Hz}), 5.10$ $(1 \mathrm{H}, \mathrm{dd}, J=11.9,2.1), 3.49(1 \mathrm{H}, \mathrm{ddd}, J=8.9,6.8,5.6 \mathrm{~Hz}), 2.94(1 \mathrm{H}$, ddd, $J=10.4 \mathrm{~Hz}, 8.0,6.8 \mathrm{~Hz}), 2.23(1 \mathrm{H}$, ddd, $J=13.9,8.0,2.1 \mathrm{~Hz})$, $1.87(1 \mathrm{H}, \mathrm{ddd}, J=13.9,11.9,10.4 \mathrm{~Hz}), 1.55(1 \mathrm{H}, \mathrm{m}), 1.40(1 \mathrm{H}, \mathrm{m})$, $0.97(3 \mathrm{H}, \mathrm{t}, J=7.4 \mathrm{~Hz}) ;{ }^{13} \mathrm{C} \mathrm{NMR}\left(75 \mathrm{MHz}, \mathrm{CDCl}_{3}\right): \delta 168.4,138.7$, 136.5, 128.6, 128.5, 128.2, 125.9, 79.1, 75.2, 43.1, 33.5, 26.1, 10.2; MS (75eV m/e) $246\left(\mathrm{M}^{+}\right)$; HRMS calcd for $\mathrm{C}_{15} \mathrm{H}_{18} \mathrm{O}_{3} 246.1255$, found 246.1257 .

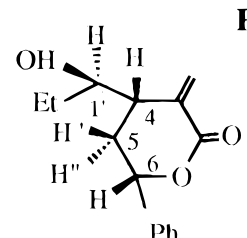

$\mathrm{Ph}$

\section{Proton NOE map of 39}

irradiation at

C(4)H proton

Intensity increase

$\mathrm{C}(5) \mathrm{H}^{\prime} 6.8 \%$; C(5)H" $2.0 \%$

C(6)H $3.3 \%$; C(1')H $2.8 \%$
Spectral data for 39t: IR (neat, $\left.\mathrm{cm}^{-1}\right) v(\mathrm{OH}), 3447, v(\mathrm{CO}) 1749,1661$; ${ }^{1} \mathrm{H}$ NMR $\left(300 \mathrm{MHz}, \mathrm{CDCl}_{3}\right) \delta 7.35-7.23(5 \mathrm{H}, \mathrm{m}), 6.24(1 \mathrm{H}, \mathrm{d}, J=$ $2.3 \mathrm{~Hz}), 5.66(1 \mathrm{H}, \mathrm{d}, J=2.3 \mathrm{~Hz}), 4.76(1 \mathrm{H}, \mathrm{dd}, J=9.4,4.0 \mathrm{~Hz}), 4.16$ (1H, ddd, $J=7.3,6.1,4.9 \mathrm{~Hz}), 2.94(1 \mathrm{H}$, ddd, $J=8.9,6.1,4.6 \mathrm{~Hz}$,), $1.98(1 \mathrm{H}$, ddd, $J=12.9,4.6,4.0 \mathrm{~Hz}), 1.82(1 \mathrm{H}, \mathrm{ddd}, J=12.9,9.4$ $, 8.9 \mathrm{~Hz}), 1.68(1 \mathrm{H}, \mathrm{m}), 1.59(1 \mathrm{H}, \mathrm{m}), 0.94(3 \mathrm{H}, \mathrm{t}, J=7.3 \mathrm{~Hz}) ;{ }^{13} \mathrm{C}$ NMR $\left(75 \mathrm{MHz}, \mathrm{CDCl}_{3}\right) \delta 170.6,144.2,139.2,128.8,128.1,125.7$, 123.0, 85.4, 71.8, 43.6, 41.5, 28.6, 9.3, MS $(75 \mathrm{eV} \mathrm{m} / \mathrm{e}) 246\left(\mathrm{M}^{+}\right)$; HRMS calcd for $\mathrm{C}_{15} \mathrm{H}_{18} \mathrm{O}_{3} 246.1255$, found 246.1257.

(14) General Procedure for Condensation of $\mathrm{CpW}(\mathrm{CO})_{2}\left(\eta^{3}-\epsilon-\right.$ Lactonyl) with Organic Carbonyls. Synthesis of $\left(4 R^{*}, 5 R^{*}\right)-\{4$ [(3S*)-3-hydroxybutyl]-3-methylene-5-phenyl-dihydrofuran-2one $\}$ (43a) and $\left(4 R^{*}, 5 R^{*}\right)\left\{4-\left[\left(3 R^{*}\right)-3\right.\right.$-hydroxybutyl]-3-methylene5-phenyldihydrofuran-2-one (43b). This compound was similarly prepared from chiral tungsten-allyl compound $\mathbf{1 4}(2.00 \mathrm{~g}, 4.50 \mathrm{mmol})$, $\mathrm{NOBF}_{4}(0.53 \mathrm{~g}, 4.50 \mathrm{mmol})$, and $\mathrm{NaI}(1.35 \mathrm{~g}, 9.10 \mathrm{mmol})$ and finally treated with benzaldehyde $(0.96 \mathrm{~g}, 9.00 \mathrm{mmol})$ at $23{ }^{\circ} \mathrm{C}$ to yield a mixture of 43a and 43b $(0.71 \mathrm{~g}, 2.88 \mathrm{mmol}, 64 \%, \mathbf{4 3 a} / \mathbf{4 3 b}=5.4 / 1)$ as a colorless oil. Pure 43a (0.45 g, $1.85 \mathrm{mmol}$ ) was obtained in $41 \%$ after elution from a preparative HPLC column (Merck, Lichroprep Si60): IR (neat, $\mathrm{cm}^{-1}$ ) 3034(br s), 1770(s), 1664(m); ${ }^{1} \mathrm{H}$ NMR (400 $\left.\mathrm{MHz}, \mathrm{CDCl}_{3}\right)$ for $43 \mathrm{a}, \delta 7.36-7.24(5 \mathrm{H}, \mathrm{m}), 6.30(1 \mathrm{H}, \mathrm{d}, J=2.5 \mathrm{~Hz})$, $5.62(1 \mathrm{H}, \mathrm{d}, J=2.5 \mathrm{~Hz}), 5.10(1 \mathrm{H}, \mathrm{d}, J=5.0 \mathrm{~Hz}), 3.73(1 \mathrm{H}, \mathrm{m}), 2.97$ $(1 \mathrm{H}, \mathrm{m}), 1.91-1.44(4 \mathrm{H}, \mathrm{m}), 1.14(3 \mathrm{H}, \mathrm{d}, J=6.2 \mathrm{~Hz})$; for $\mathbf{4 3 b}$, selected signals, $3.75(1 \mathrm{H}, \mathrm{m}), 1.17(3 \mathrm{H}, \mathrm{d}, J=6.2 \mathrm{~Hz})$, the remaining signals masked exactly with those of $43 \mathrm{a} ;{ }^{13} \mathrm{C} \mathrm{NMR}\left(100 \mathrm{MHz}, \mathrm{CDCl}_{3}\right) \mathbf{4 3 a}$, $\delta 170.3,139.3,138.5,128.8,128.6,125.7,122.7,84.2,67.6,47.4,35.3$, 29.6, 25.6, 43b, $\delta 170.3,139.3,138.5,128.8,128.6,125.7,122.7,84.1$, 67.4, 47.3, 35.3, 29.6, 23.6; MS (75eV m/e) $246\left(\mathrm{M}^{+}\right)$; HRMS calcd for $\mathrm{C}_{15} \mathrm{H}_{18} \mathrm{O}_{3}$ 246.1256, found 246.1249 .

(15) Synthesis of $\left(4 R^{*}, 5 R^{*}\right)$-[3-methylene-4-[(3S*)-3-(triethylsiloxy)butyl]-5-phenyldihydrofuran-2-one] (49). To a DMF solution $(5 \mathrm{~mL})$ of 43a $(0.59 \mathrm{~g}, 2.40 \mathrm{mmol})$ and 2,6-lutidine $(0.42 \mathrm{~g}, 3.60 \mathrm{~mL})$ was added triethylsilyl chloride $(0.40 \mathrm{~g}, 2.40 \mathrm{mmol})$; the mixture was stirred for $8 \mathrm{~h}$ before sequential addition of an aqueous $\mathrm{NH}_{4} \mathrm{Cl}(2 \mathrm{~mL})$. The solution was extracted with diethyl ether $(3 \times 20 \mathrm{~mL})$ and flash chromatographed through a short silica cloumn to yield $\mathbf{4 9}$ as a colorless oil $(0.80 \mathrm{~g}, 2.21 \mathrm{mmol}, 92 \%)$ : IR (neat, $\left.\mathrm{cm}^{-1}\right)$ 3035(br s), 1770(s), 1664(m), 1604(m); ${ }^{1} \mathrm{H}$ NMR $\left(400 \mathrm{MHz}, \mathrm{CDCl}_{3}\right) \delta 7.37-7.24(5 \mathrm{H}$, $\mathrm{m}), 6.33(1 \mathrm{H}, \mathrm{d}, J=2.6 \mathrm{~Hz}), 5.61(1 \mathrm{H}, \mathrm{d}, J=2.6 \mathrm{~Hz}), 5.10(1 \mathrm{H}, \mathrm{d}$, $J=5.1 \mathrm{~Hz}), 3.75(1 \mathrm{H}, \mathrm{m}), 2.96(1 \mathrm{H}, \mathrm{m}), 1.86-1.43(4 \mathrm{H}, \mathrm{m}), 1.10$ $(3 \mathrm{H}, \mathrm{d}, J=6.4 \mathrm{~Hz}), 0.91(9 \mathrm{H}, \mathrm{t}, J=7.6 \mathrm{~Hz}) 0.56(6 \mathrm{H}, \mathrm{q}, J=7.6 \mathrm{~Hz})$; ${ }^{13} \mathrm{C} \mathrm{NMR}\left(100 \mathrm{MHz}, \mathrm{CDCl}_{3}\right) \delta 170.2,139.5,138.8,128.8,128.6,125.8$, 122.4 , 84.0, 67.9, 47.6, 35.9, 29.3, 23.8, 6.8, 4.9; MS (75eV m/e) 360 $\left(\mathrm{M}^{+}\right)$; HRMS calcd for $\mathrm{C}_{21} \mathrm{H}_{32} \mathrm{SiO}_{3} 360.2121$, found 360.2118 .

(16) Synthesis of $\left(4 R^{*}, 7 S^{*}\right)$-[4-[( $\left.R^{*}\right)$-hydroxyphenylmethyl]-2methyl-3-methyleneoctane-2,7-diol] (50). To a THF (5.0 mL) solution of $49(0.70 \mathrm{mg}, 1.94 \mathrm{mmol})$ was added a hexane solution of MeLi (1.6 $\mathrm{M}, 6.08 \mathrm{~mL}$ ) at $-78^{\circ} \mathrm{C}$, and the solution was brought to $23^{\circ} \mathrm{C}$. The solution was treated with aqueous $\mathrm{NH}_{4} \mathrm{Cl}(5.0 \mathrm{M}, 1 \mathrm{~mL})$, concentrated to $\sim 3 \mathrm{~mL}$, and extracted with diethyl ether $(2 \times 5 \mathrm{~mL})$. Flash chromatography afforded $\mathbf{5 0}$ as a colorless solid $(0.44 \mathrm{~g}, 1.57 \mathrm{~mol}$, 81\%): IR (neat, $\mathrm{cm}^{-1}$ ) 3306(br vs), $1640(\mathrm{~m}) ;{ }^{1} \mathrm{H}$ NMR $(400 \mathrm{MHz}$, $\left.\mathrm{CDCl}_{3}\right) \delta 7.36-7.26(5 \mathrm{H}, \mathrm{m}), 5.27(1 \mathrm{H}, \mathrm{s}), 5.02(1 \mathrm{H}, \mathrm{s}), 4.29(1 \mathrm{H}, \mathrm{d}$, 
$J=9.5 \mathrm{~Hz}), 3.69$ (br, OH), 3.53 (1H, m), 3.10 (br), 2.81 (1H, ddd, $J$ $=9.5,8.8,8.5 \mathrm{~Hz}), 1.69(\mathrm{br}, \mathrm{OH}), 1.46(3 \mathrm{H}, \mathrm{s}), 1.36-1.00(4 \mathrm{H}, \mathrm{m})$, $1.27(3 \mathrm{H}, \mathrm{s}), 0.99(3 \mathrm{H}, \mathrm{d}, J 6.1 \mathrm{~Hz}) ;{ }^{13} \mathrm{C} \mathrm{NMR}\left(100 \mathrm{MHz}, \mathrm{CDCl}_{3}\right) \delta$ 157.6, 143.6, 128.5, 128.2, 127.2, 108.5, 81.4, 72.2, 68.2, 45.9, 36.9, 29.9, 29.7, 28.8, 23.2; MS (75eV m/e) $278\left(\mathrm{M}^{+}\right)$; HRMS calcd for $\mathrm{C}_{17} \mathrm{H}_{26} \mathrm{O}_{3} 278.1881$, found 278.1881 .

(17) Synthesis of $\left(1 R^{*}, 2 R^{*}\right)$-[2-[(3S*)-3-methanesulfonylbutyl]4-methyl-3-methylene-1-phenylpentane-1,4-diol] (51). To $50(0.43$ $\mathrm{g}, 1.55 \mathrm{mmol})$ in $\mathrm{Et}_{3} \mathrm{~N}(0.43 \mathrm{~mL})$ was added DMAP $(57.1 \mathrm{mg}, 0.47$ mmol $)$ and methanesulfonic chloride $(20.0 \mu \mathrm{L}, 1.55 \mathrm{mmol})$. The solution was stirred for $1 \mathrm{~h}$ before aqueous $\mathrm{NH}_{4} \mathrm{Cl}$ was added. Flash chromatography gave $51(0.53 \mathrm{~g}, 1.47 \mathrm{mmol}, 95 \%)$ : IR (neat, $\mathrm{cm}^{-1}$ ) 3454(br vs) $1644(\mathrm{~m}) ;{ }^{1} \mathrm{H}$ NMR $\left(400 \mathrm{MHz}, \mathrm{CDCl}_{3}\right) \delta 7.31-7.24(5 \mathrm{H}$, $\mathrm{m}), 5.26(1 \mathrm{H}, \mathrm{s}), 4.99(1 \mathrm{H}, \mathrm{s}), 4.51(1 \mathrm{H}, \mathrm{m}), 4.23(1 \mathrm{H}, \mathrm{d}, J=9.6 \mathrm{~Hz})$, $3.66(\mathrm{br}, \mathrm{OH}), 2.75(1 \mathrm{H}, \mathrm{m}), 2.69(3 \mathrm{H}, \mathrm{s}), 1.51-1.17(4 \mathrm{H}, \mathrm{m}), 1.44$ $(3 \mathrm{H}, \mathrm{s}), 1.25(3 \mathrm{H}, \mathrm{s}), 1.22(3 \mathrm{H}, \mathrm{d}, J=6.3 \mathrm{~Hz}) ;{ }^{13} \mathrm{C}$ NMR $(100 \mathrm{MHz}$, $\left.\mathrm{CDCl}_{3}\right) \delta 157.6,143.6,128.5,128.2,127.2,108.7,81.5,80.3,72.0$, 45.7, 38.3, 34.3, 29.8, 29.6, 28.1, 21.1; MS (75eV m/e) $356\left(\mathrm{M}^{+}\right)$; HRMS calcd for $\mathrm{C}_{18} \mathrm{H}_{28} \mathrm{SO}_{5} 356.1657$, found 356.1654 .

(18) Synthesis of [2-methyl-3-[(2R*,3R*,6R*)-6-methyl-2-phenyltetrahydropyran-3-yl]but-3-en-2-ol] (52). To 51 (0.41 g, 1.15 $\mathrm{mmol})$ in DMF $(5 \mathrm{~mL})$ was added $\mathrm{NaH}(0.11 \mathrm{~g}, 4.60 \mathrm{mmol})$, and the mixture was heated at $50{ }^{\circ} \mathrm{C}$ for $4 \mathrm{~h}$. The solution was extracted with diethyl ether $(3 \times 15 \mathrm{~mL})$, and flash chromatographed through a short silica column to yield $\mathbf{5 2}$ as a colorless solid $(0.28 \mathrm{~g}, 1.06 \mathrm{mmol}$, 92\%): IR (neat, $\mathrm{cm}^{-1}$ ) 3431(br vs), 1642 (m); ${ }^{1} \mathrm{H}$ NMR (400 MHz, $\left.\mathrm{CDCl}_{3}\right) \delta 7.40-7.11(5 \mathrm{H}, \mathrm{m}), 5.55(1 \mathrm{H}, \mathrm{s}), 5.16(1 \mathrm{H}, \mathrm{s}), 4.70(1 \mathrm{H}, \mathrm{d}$, $J=3.2 \mathrm{~Hz}), 3.66(1 \mathrm{H}, \mathrm{m}), 2.72(1 \mathrm{H}, \mathrm{m}), 2.03$ and $1.82(2 \mathrm{H}, \mathrm{m}), 1.71-$ $1.43(2 \mathrm{H}, \mathrm{m}), 1.30(3 \mathrm{H}, \mathrm{d}, J=6.1 \mathrm{~Hz}), 0.98(3 \mathrm{H}, \mathrm{s}), 0.95(3 \mathrm{H}, \mathrm{s}) ;{ }^{13} \mathrm{C}$ NMR $\left(100 \mathrm{MHz}, \mathrm{CDCl}_{3}\right) \delta 152.1,142.0,127.4,126.5,126.4,112.7$, 81.9, 74.7, 73.3, 37.7, 29.9, 28.5, 28.1, 27.2, 22.3; MS (75 eV m/e) $260\left(\mathrm{M}^{+}\right)$; HRMS calcd for $\mathrm{C}_{17} \mathrm{H}_{24} \mathrm{O}_{2} 260.1776$, found 260.1776. In the proton NOE experiment, irradiation of the $\mathrm{C}(2) \mathrm{H}(\delta 4.70)$ signal enhanced the $\mathrm{C}(6) \mathrm{H}$ and $\mathrm{C}(3) \mathrm{H}$ proton intensities by 4.8 and $3.2 \%$, respectively. The magnitudes $J_{23}=2.3 \mathrm{~Hz}$ and $J_{5^{\prime \prime} 6}=2.3 \mathrm{~Hz}$ are consistent with the axial-equatorial coupling whereas the $J_{5^{\prime} 6}=11.4$ $\mathrm{Hz}$ value is a typical axial-axial coupling constant. Based on these data, the configuration of $\mathbf{5 2}$ was assigned.

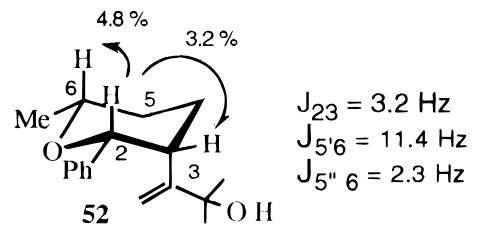

(19) Synthesis of the Nitrosyl Salt of 19. To a $\mathrm{CH}_{3} \mathrm{CN}(5 \mathrm{~mL})$ solution of $19(0.90 \mathrm{~g}, 1.83 \mathrm{mmol})$ was added with $\mathrm{NOPF}_{6}(0.32 \mathrm{~g}$, $1.83 \mathrm{mmol}$ ) at $0{ }^{\circ} \mathrm{C}$; the mixture was stirred for $30 \mathrm{~min}$. The solution was concentrated to $\sim 1 \mathrm{~mL}$; addition of diethyl ether $(20 \mathrm{~mL})$ yielded a yellow viscous solid that was dried in vacuo for $24 \mathrm{~h}$. Recrystallization of this solid in a $\mathrm{CH}_{3} \mathrm{CN} /$ diethyl ether solution yielded red orange crystals of $\mathbf{5 3}$ (1.00 g, $1.56 \mathrm{mmol}, 85 \%)$ : IR (Nujol, $\mathrm{cm}^{-1}$ ) $v$ (CO) 2077(s), 1732(s), $v$ (NO) 1632(vs); ${ }^{1} \mathrm{H}$ NMR (400 MHz, $\mathrm{CD}_{3} \mathrm{CN},-33$ $\left.{ }^{\circ} \mathrm{C}\right) \delta 7.56-7.48(5 \mathrm{H}, \mathrm{m}, \mathrm{Ph}), 6.48(5 \mathrm{H}, \mathrm{s}, \mathrm{Cp}), 5.32(1 \mathrm{H}, \mathrm{dd}, J=$ $11.7,3.6 \mathrm{~Hz}), 5.05(1 \mathrm{H}, \mathrm{d}, J=3.6 \mathrm{~Hz}), 5.04(1 \mathrm{H}, \mathrm{d}, J=3.4 \mathrm{~Hz}), 3.84$ $(1 \mathrm{H}, \mathrm{ddd}, J=17.8,11.7 \mathrm{~Hz}), 3.10(1 \mathrm{H}, \mathrm{dt}, J=17.8,3.6 \mathrm{~Hz}), 2.73$ $(1 \mathrm{H}, \mathrm{d}, J=3.4 \mathrm{~Hz}) ;{ }^{13} \mathrm{C}$ NMR $\left(100 \mathrm{MHz}, \mathrm{CD}_{3} \mathrm{CN}, 253 \mathrm{~K}\right) \delta 163.6$, $108.5,101.5,98.2,80.3,36.3,30.2,28.2,9.4$. Anal. Calcd for $\mathrm{C}_{18} \mathrm{H}_{16} \mathrm{WO}_{4} \mathrm{NPF}_{6}$ : C, 33.80; H, 2.52; N, 2.19. Found: C, 33.86; H, $2.61 ; \mathrm{N}, 2,13$.

(20) Synthesis of the Iodo Derivative of 53. To a $\mathrm{CH}_{3} \mathrm{CN}(5.0$ $\mathrm{mL})$ solution of $\mathbf{5 3}(0.500 \mathrm{~g}, 1.01 \mathrm{mmol})$ was added $\mathrm{NaI}(0.30 \mathrm{~g}, 2.02$ mmol) at $0{ }^{\circ} \mathrm{C}$; the solution was stirred for $30 \mathrm{~min}$ and evaporated to dryness. The residue was washed with diethyl ether and then extracted with $\mathrm{CH}_{2} \mathrm{Cl}_{2}(2 \times 5 \mathrm{~mL})$. The extract was concentrated and recrystallized from $\mathrm{CH}_{3} \mathrm{CN} /$ diethyl ether to give $\mathbf{5 5}$ as dark red plates $(0.50 \mathrm{~g}$, $0.84 \mathrm{mmol}, 83 \%$ ): IR (Nujol, $\mathrm{cm}^{-1}$ ) $v(\mathrm{CO}) 1717(\mathrm{~s}), v(\mathrm{NO}) 1640 ;{ }^{1} \mathrm{H}$ NMR (400 MHz, $\left.\mathrm{CDCl}_{3}, 243 \mathrm{~K}\right) \delta 7.40-7.30(5 \mathrm{H}, \mathrm{m}, \mathrm{Ph}), 6.03(5 \mathrm{H}$, s, Cp), $5.80(1 \mathrm{H}, \mathrm{dd}, J=12.0,3.4 \mathrm{~Hz}), 5.11(1 \mathrm{H}, \mathrm{d}, J=3.4 \mathrm{~Hz}), 3.77$ $(1 \mathrm{H}, \mathrm{d}, J=4.0 \mathrm{~Hz}), 3.45(1 \mathrm{H}, \mathrm{dd}, J=18.0,12.0 \mathrm{~Hz}), 3.09(1 \mathrm{H}, \mathrm{dt}, J$ $=18.0,3.4 \mathrm{~Hz}), 1.91(1 \mathrm{H}, \mathrm{d}, J=4.0 \mathrm{~Hz}) ;{ }^{13} \mathrm{C} \mathrm{NMR}\left(100 \mathrm{MHz}, \mathrm{CDCl}_{3}\right.$, $\left.-30^{\circ} \mathrm{C}\right) \delta 163.4,138.2,128.8,128.4,126.1,108.4,100.9,95.7,79.3$, 36.2, 25.5; MS $(12 \mathrm{eV}, \mathrm{m} / \mathrm{e}) 593\left(\mathrm{M}^{+}\right)$. Anal. Calcd for $\mathrm{C}_{17} \mathrm{H}_{16} \mathrm{O}_{3^{-}}$ NIW: C, 34.43; H, 2.72; N, 2.36. Found: C, 34.41; H, 2.72; N, 2.33.

(21) Synthesis of 54. To a stirring $\mathrm{CH}_{3} \mathrm{CN}(5 \mathrm{~mL})$ solution of 18 $(0.50 \mathrm{~g}, 1.13 \mathrm{mmol})$ was added with $\mathrm{NOPF}_{6}(0.20 \mathrm{~g}, 1.13 \mathrm{mmol})$ at 0 ${ }^{\circ} \mathrm{C}$, and the mixture was stirred for $30 \mathrm{~min}$ before addition of $\mathrm{NaI}(0.34$ $\mathrm{g}, 2.26 \mathrm{mmol}$ ). After being stirred for additional $30 \mathrm{~min}$, the solution was evaporated to dryness, washed with diethyl ether, and then extracted with $\mathrm{CH}_{2} \mathrm{Cl}_{2}(2 \times 5 \mathrm{~mL})$. The extract was dried in vacuo and recrystallized from $\mathrm{CH}_{3} \mathrm{CN} /$ diethyl ether to give $\mathbf{5 4}$ as dark red plates (0.43 g, $0.81 \mathrm{mmol}, 72 \%$ ): IR (neat, $\left.\mathrm{cm}^{-1}\right) v(\mathrm{CO}) 1720(\mathrm{~s}), v(\mathrm{NO}) 1641$; ${ }^{1} \mathrm{H}$ NMR $\left(400 \mathrm{MHz}, \mathrm{CD}_{2} \mathrm{Cl}_{2}\right)$ major conformer $\left(-33{ }^{\circ} \mathrm{C}\right), \delta 5.97(5 \mathrm{H}$, s), $5.06(1 \mathrm{H}, \mathrm{d}, J=3.1 \mathrm{~Hz}), 4.57(1 \mathrm{H}, \mathrm{m}), 3.60(1 \mathrm{H}, \mathrm{d}, J=4.0 \mathrm{~Hz})$, $3.17(1 \mathrm{H}, \mathrm{dd}, J=16.1,10.6), 2.86(1 \mathrm{H}, \mathrm{dt}, J=16.1,3.1 \mathrm{~Hz}), 1.80$ $(1 \mathrm{H}, \mathrm{d}, J=4.0 \mathrm{~Hz}), 1.80-1.61(2 \mathrm{H}, \mathrm{m}), 0.90(3 \mathrm{H}, \mathrm{t}, J=6.3 \mathrm{~Hz})$; minor conformer $\left(20^{\circ} \mathrm{C}\right), \delta, 5.85(\mathrm{~s}, 5 \mathrm{H}), 5.05(1 \mathrm{H}, \mathrm{br} \mathrm{s}), 4.05(1 \mathrm{H}, \mathrm{br}$ s), $3.60(1 \mathrm{H}, \mathrm{dd}, J=16.0,10.2 \mathrm{~Hz}), 3.10(1 \mathrm{H}, \mathrm{dt}, J=16.1,3.1 \mathrm{~Hz})$, $2.40(1 \mathrm{H}$, br s), the rest signals were masked by those of major diastereomer; ${ }^{13} \mathrm{C}$ NMR (100 MHz, $\left.\mathrm{CD}_{2} \mathrm{Cl}_{2}, 243 \mathrm{~K}\right) \delta 163.6,108.5$, 101.5, 98.2, 80.3, 36.3, 30.2, 28.3, 9.4. MS $(12 \mathrm{eV}, \mathrm{m} / \mathrm{e}) 529\left(\mathrm{M}^{+}\right)$. Anal. Calcd for $\mathrm{C}_{13} \mathrm{H}_{16} \mathrm{O}_{3}$ WNI: C, 28.63; H, 2.96; N, 2.57. Found: C, 28.60; H, 2.98; N, 2.55 .

X-ray Diffraction Studies of 14, 50, and 53. Crystal data and data collection of $9, \mathbf{1 8}, \mathbf{1 9}, \mathbf{2 4}$, and 27 have appeared in the communication of this article; ${ }^{13}$ they will not be reported here. Single crystals of 14, $\mathbf{5 0}$, and $\mathbf{5 3}$ were sealed in glass capillaries under an inert atmosphere. Data for $\mathbf{5 0}$ and $\mathbf{5 3}$ were collected on a Nonius CAD 4 using graphitemonochromated Mo K $\alpha$ radiation. The structures of $\mathbf{5 0}$ and $\mathbf{5 3}$ was solved by direct and heavy-atom methods, respectively; all data reduction and structural refinements were performed with NRCCSDP package. Data for $\mathbf{1 4}$ were collected on a Siemens SMART CCD diffractometer using graphite-monochromated Mo K $\alpha$ radiation, and the structure was solved by direct methods; all data reduction and structural refinement were performed with the Siemens SHELXTL Plus package. Crystal data, details of data collection, and structural analysis of these three compounds are prepared as supporting information. For all structures, all non-hydrogen atoms were refined with anisotropic parameters, and all hydrogen atoms included in the structure factor were placed in idealized positions.

Acknowledgment. The authors wish to thank the National Science Council and National Institute of Health, Taiwan, for financial support of this work.

Supporting Information Available: Syntheses and spectral data of compounds of the same family $\mathbf{9 - 1 1}, \mathbf{1 9}, \mathbf{2 0}, \mathbf{2 5}, \mathbf{2 7}$, 30-35, 37, 40-42, 44-48, and 55 in the repetitive operations; variable-temperature ${ }^{1} \mathrm{H}$ NMR spectra of 54; tables of crystal data, structural parameters, and ORTEP drawings of 14, 50, and $\mathbf{5 3}$ (32 pages). Ordering information is given on any current masthead page.

JA9617808 